OPEN ACCESS

Edited by:

Pei-Hui Wang,

Shandong University, China

Reviewed by:

Yuriy L. Orlov,

I.M.Sechenov First Moscow State Medical University, Russia Konstantin Kandror,

Boston University, United States

Sabyasachi Dash,

NewYork-Presbyterian, Weill Cornell

Medical Center, United States

Bodu Liu,

Cold Spring Harbor Laboratory, United States

*Correspondence:

Evgeny Knyazev

knyazevevg@gmail.com

Specialty section: This article was submitted to Viral Immunology,

a section of the journal

Frontiers in Immunology

Received: 05 December 2020

Accepted: 20 August 2021

Published: 07 September 2021

Citation:

Knyazev E, Nersisyan S and Tonevitsky A (2021) Endocytosis and

Transcytosis of SARS-CoV-2

Across the Intestinal Epithelium

and Other Tissue Barriers.

Front. Immunol. 12:636966. doi: 10.3389/fimmu.2021.636966

\section{Endocytosis and Transcytosis of SARS-CoV-2 Across the Intestinal Epithelium and Other Tissue Barriers}

\author{
Evgeny Knyazev ${ }^{1,2 *}$, Stepan Nersisyan ${ }^{2}$ and Alexander Tonevitsky ${ }^{1,2}$ \\ ${ }^{1}$ Laboratory of Microfluidic Technologies for Biomedicine, Shemyakin-Ovchinnikov Institute of Bioorganic Chemistry of the \\ Russian Academy of Sciences, Moscow, Russia, ${ }^{2}$ Faculty of Biology and Biotechnology, National Research University Higher \\ School of Economics (HSE), Moscow, Russia
}

Since 2003, the world has been confronted with three new betacoronaviruses that cause human respiratory infections: SARS-CoV, which causes severe acute respiratory syndrome (SARS), MERS-CoV, which causes Middle East respiratory syndrome (MERS), and SARS-CoV-2, which causes Coronavirus Disease 2019 (COVID-19). The mechanisms of coronavirus transmission and dissemination in the human body determine the diagnostic and therapeutic strategies. An important problem is the possibility that viral particles overcome tissue barriers such as the intestine, respiratory tract, blood-brain barrier, and placenta. In this work, we will 1) consider the issue of endocytosis and the possibility of transcytosis and paracellular trafficking of coronaviruses across tissue barriers with an emphasis on the intestinal epithelium; 2) discuss the possibility of antibody-mediated transcytosis of opsonized viruses due to complexes of immunoglobulins with their receptors; 3) assess the possibility of the virus transfer into extracellular vesicles during intracellular transport; and 4) describe the clinical significance of these processes. Models of the intestinal epithelium and other barrier tissues for in vitro transcytosis studies will also be briefly characterized.

Keywords: SARS-CoV-2, COVID-19, coronavirus, intestines, gastrointestinal tract, microfluidics, transcytosis, endocytosis

\section{INTRODUCTION}

At the moment, it remains unclear whether the gastrointestinal tract can serve as an entry portal for SARS-CoV-2; however, fecal-oral transmission is considered likely (1). There is a concern that SARS-CoV-2 transmission may occur via frozen foods or packaging (2), so the fate of the coronavirus in the intestine is relevant. SARS-CoV-2 RNA was detected in feces of infected people in $>50 \%$ of cases, and $>20 \%$ of patients continued to have positive stool results after negative respiratory sample results (3). The SARS-CoV-2 nucleocapsid $(\mathrm{N})$ protein was found in the cytoplasm of gastric, duodenal, and rectal epithelial cells. Viral RNA was also detected in samples of the esophageal mucosa, although the N-protein was not detected in esophageal epithelial cells (3). A systematic review and meta-analysis of 35 studies showed that $\sim 15 \%$ of patients had digestive symptoms including nausea, vomiting, and diarrhea, while $10 \%$ of patients had gastrointestinal symptoms alone without respiratory features (4). According to electron 
microscopy and virus culture data, active viral replication of SARS-CoV-2 was detected in both the small and large intestines (5). SARS-CoV-2 cell entry depends on angiotensin-converting enzyme 2 (ACE2) and transmembrane serine protease 2 (TMPRSS2) (6), which are both expressed on the luminal surface of cells in the gastrointestinal tract $(3,7)$. SARS-CoV-2 can cause productive infection of human enterocytes (8). These facts support the possibility of fecal-oral transmission of SARS$\mathrm{CoV}-2$, and underscore the need to elucidate possible mechanisms of coronavirus penetration through tissue barriers, including in the intestine.

\section{NATIVE AND OPSONIZED CORONAVIRUSES}

To understand and model the processes of endocytosis and transcytosis of SARS-CoV-2 in the intestine and other barrier organs, it is necessary to have a clear understanding of the structure of native virions, including their size, the number of cell-interacting spikes on the virion surface, the mechanism and stoichiometric ratios in the interaction of spines with receptors and antibodies, and corresponding structural limitations.

A combination of cryoelectron tomography and subtomogram averaging for a study of 2300 intact SARSCoV-2 virions showed ellipsoidal envelope particles with average diameters of $64.8 \pm 11.8,85.9 \pm 9.4$, and $96.6 \pm 11.8$ $\mathrm{nm}$ (average \pm SD) for the short, medium, and long axes of the envelope, respectively (9). About $97 \%$ of spike (S) protein trimers in this virion sample were in prefusion conformation and 3\% in postfusion, with each virion having an average of $26 \pm 15$ spikes in prefusion conformation and each spike freely changing the angle relative to the virion membrane (9). In another study, the average virion diameter, if taken as spherical, was $91 \pm 11 \mathrm{~nm}$, and each virion had $24 \pm 9$ S-protein trimers, $3 \%$ of which were in postfusion conformation. A small sub-population of virions contained only few S trimers, while larger virions contained more $S$ trimers. There was approximately one spike per 1,000 $\mathrm{nm}^{2}$ of virus membrane (10). For comparison, there were approximately 10 spikes of the influenza A virus per $1,000 \mathrm{~nm}^{2}$ of membrane surface with a virion diameter of 80-120 nm (11). That is, the distances between the spikes of the influenza A and SARS-CoV-2 are approximately $11 \mathrm{~nm}$ and $35 \mathrm{~nm}$, respectively. In another study, $<0.1 \%$ of SARS-CoV-2 S-protein trimers were in postfusion conformation, which can be explained by the type of cells in which virions were produced, including the number of receptors and proteases involved in the transition of receptors into postfusion conformation (12). As it was shown, each virion had an average of 40 spikes evenly distributed over the surface without a tendency of agglomeration (12). Each trimer freely bent at an angle to the membrane due to a stalk with three flexible hinges. In contrast to recombinant S-proteins, trimers synthesized in infected cells were much more densely covered with glycans, mainly due to N-glycosylation (12).

The free arrangement and rotation of S-protein trimers apparently helps the virus to "explore" the surrounding space, allowing several spikes to interact with one ACE2 receptor or one spike with several ACE2 molecules simultaneously (9). The ACE2 homodimer can interact with two S-proteins of two different spikes, in which one $S$ protein is in an up conformation, and the other two are in down conformations (13). D. Ni and colleagues (14) published work indicating possibility of the simultaneous interaction of three free ACE2 ectodomains with the SARS-CoV-2 trimeric spike, which led to the transition of all three S-proteins into up conformation and disassembly of the trimeric form. Although the conclusions of this investigation must be peer-reviewed, preliminary conclusions can be drawn about the possibility of the S-protein trimer interacting with more than one ACE2 molecule. In another study, SARS-CoV-2 S-protein trimers were mixed with ACE2 molecules in the presence or absence of dp20 oligosaccharides derived from heparin. After incubation for 60 minutes, transmission electron microscopy revealed that in the absence of $\mathrm{dp} 20$ oligosaccharides, the proportions of S-protein trimers bound to one, two, and three ACE2 molecules were 45\%, 11\%, and 13\%, respectively, and in the presence of dp20 oligosaccharides the corresponding values were $40 \%, 19 \%$, and $27 \%$. The authors concluded that each SARS-CoV-2 spike can interact with more than one ACE2 molecule, and the presence of heparin can stabilize this interaction (15).

The sparse arrangement and free rotation of SARS-CoV-2 spikes also makes them more vulnerable to neutralizing antibodies, which provides an additional opportunity to bind to hard-to-reach domains (16) and glycan holes of the S protein (17). An immunoglobulin G (IgG) molecule can potentially bind both to one coronavirus spike and two adjacent spikes due to two Fab domains of IgG (18). Cryoelectron microscopy has also shown that one trimer of the SARS-CoV-2 S protein can bind to either one or two or three Fab domains $(19,20)$, potentially indicating the ability to bind up to three antibodies to one SARS-CoV-2 spike. Another study showed the bivalent interaction of full-length IgG with a trimer of the SARS-CoV-2 S-protein (21). Given the linear dimensions of antibodies (22), it can be assumed that an IgG-coated SARS-CoV-2 virion will have a diameter no more than $20 \mathrm{~nm}$ larger than the free virion. When interacting with polymeric immunoglobulin A (IgA) and $\mathrm{M}(\operatorname{IgM})$, the size may increase even more. Ig molecules can also bind to spikes of neighboring virions, leading to the formation of agglomerates.

Thus, the coronavirus can interact with target cells both in the form of a free virion and in the form of an opsonized virion or viral agglomerates, cross-linked by antibodies. In each case, the particle size and molecules available on their surface can determine various mechanisms of endocytosis and subsequent intracellular transport. Possible mechanisms of coronavirus binding to target cells are briefly discussed below.

\section{HOW CORONAVIRUSES BIND CELLS}

The process of virus penetration into the body through barrier tissues begins with cell binding. The fate of the virus may depend 
on many factors including the shape and structure of the virion, the structure and number of cell receptors and the corresponding virus-binding molecules, the possibility of dimerization/ polymerization of these receptors and molecules, the structure of the membrane surrounding the receptors (e.g., lipid rafts, etc.). Viruses can penetrate and infect cells of barrier tissues directly through the cytoplasmic membrane and indirectly by using cell endocytosis pathways. A number of viruses can also be internalized by the cell and cross the tissue barrier due to transcytosis $(23,24)$. There are several distinct stages in the process of virus interaction with a cell, including attachment to the cell surface, lateral movement along the cytoplasmic membrane and receptor clustering, activation of cellular signaling pathways, endocytosis and transport to secondary organelles, cell entry by fusion, lysis or pore/channel formation, intracellular transport to the nucleus or compartments within the cytoplasm, and complete or partial uncoating of viral particles (24).

Since viral particles can simultaneously bind several molecules on the cell surface, virions are more likely to bind to microdomains of the cell membrane containing receptor clusters, leading to further clustering of receptors or rearrangement of these microdomains (25). We noted above that SARS-CoV-2 has a high degree of spike mobility, and each one can bind to several molecules on the cell surface, which facilitates receptor clustering and virus cell entry. A ganglioside-binding domain was predicted in the N-terminal domain of the SARS-CoV-2 S-protein, which may be responsible for the binding of coronavirus spikes to lipid rafts rich in gangliosides and sialic acids (26). Molecular mimicry was also observed between azithromycin and ganglioside sugars, and it was suggested that the decrease in viral load following azithromycin treatment for COVID-19 can be explained by the fact that azithromycin binds SARS-CoV-2 S-proteins, preventing their interaction with lipid rafts (27). Other coronaviruses have also shown tropism for membrane microdomains. For MERS$\mathrm{CoV}$, tetraspanin CD9 in the cell membrane microdomains promotes the formation of complexes of the MERS-CoV receptor dipeptidyl peptidase 4 (DPP4) and the TMPRSS2 molecule with effective early cell entry of the virus; in the absence of this tetraspanin, MERS-CoV was not activated by membrane serine proteases, so it was transported to endosomes and activated by cathepsins (28). For SARS-CoV, ACE2 receptor concentration in cholesterol-rich lipid rafts is important for virus cell entry. Destroying lipid rafts while maintaining ACE2 expression significantly reduced the virus ability to enter the cell $(29,30)$. Since the cell entry mechanisms of SARS-CoV-2 and SARS-CoV are similar, it can be assumed that cytoplasmic membrane microdomains also play an important role in the interaction between cells and SARS-CoV-2.

Intracellular viral fate may depend on whether a free virion or an opsonized viral particle attaches to the cell surface, since distinct receptors are involved in virus attachment for these scenarios. For adenoviruses and rhinoviruses, it is assumed that aggregates of virions enter the cell in a different way than individual viral particles $(31,32)$, which may also be important for coronaviruses. The following section discusses potential mechanisms of coronaviruses bind to cells of barrier.

\section{Binding of Native Virions Through the Interaction of S-Proteins and Specific Target Cell Receptor Molecules}

For SARS-CoV, SARS-CoV-2, and MERS-CoV, mechanisms of cell entry by interacting with specific target molecules are known: ACE2 for SARS-CoV and SARS-CoV-2 and DPP4 for MERS$\mathrm{CoV}$ (33). S-proteins of coronaviruses are typical class I fusion proteins that require prefusion cleavage with proteases such as furin, cathepsins, TMPRSS2 and TMPRSS4, human airway trypsin-like protease (HAT), trypsin, thermolysin, and elastase, depending on the virus and cell type $(34,35)$. S-protein cleavage by proteases is necessary to initiate fusion of the virus and cell membranes, which occurs during endocytosis. Interestingly, cleavage of the ACE2 receptor molecule was also noted, followed by SARS-CoV virus endocytosis (36) and the further possibility of transcytosis or cytoplasmic penetration through late endolysosomes/lysosomes.

There are recent reports that neuropilin-1 (NRP1) protein can serve as another SARS-CoV-2 receptor $(37,38)$. This protein interacts with furin-cleaved substrates, and the interaction of furin-cleaved SARS-CoV-2 S protein and NRP1 was confirmed using crystallographic and biochemical approaches. Inhibition of this interaction by RNA interference or selective inhibitors reduced SARS-CoV-2 infectivity in vitro (38). Conversely, NRP1 overexpression enhances SARS-CoV-2 infectivity in vitro, and monoclonal antibodies to NRP1 counteract this effect. A mutation in the furin cleavage site of the SARS-CoV-2 S-protein resulted in loss of the dependence of virus infectivity on NRP1 level. Interestingly, olfactory neuronal cells highly express NRP1, which may explain the COVID-19 symptom of anosmia (37). These data indicate that beyond ACE2, SARS$\mathrm{CoV}-2$ may have one more specific receptor on the surface of target cells. In addition to the specific mechanism of viral penetration into the cell through interaction of a receptor molecule with coronavirus spikes, there is also the possibility of absorption of opsonized viral particles due to the interaction of the fragment crystallizable $(\mathrm{Fc})$ region of antibodies with $\mathrm{Fc}$ receptors on the target cell surface.

\section{Binding of Opsonized Virions Through Interactions Between Immunoglobulins and Their Receptors}

Normally, opsonized virion absorption with aid of the Fc receptors is aimed at neutralizing viral particles by immune cells; however, there is a phenomenon of antibody-dependent enhancement (ADE) that occurs when a low level of antibodies or their low neutralizing activity can contribute to cellular infection with opsonized viruses (39). Fc receptors are also present on the surface of epithelial cells of the gastrointestinal tract, respiratory system, kidneys, liver, and placental trophoblast (40), which also raises the possibility of antibody-mediated penetration of coronaviruses into these cells and transcytosis through tissue barriers. Detailed investigation of the mechanism of SARS-CoV-2 neutralization with antibodies is a very urgent task since it underlies the action of vaccines and the use of blood plasma of people who recovered from COVID-19, 
immunoglobulins obtained from this plasma, and recombinant antibodies and their fragments directed against viral proteins (41, 42). In this case, the most important parameters are the titer and antigenic specificity of neutralizing antibodies necessary to suppress a viral infection (41). When choosing the antibody concentration, it is necessary to consider the possibility of antibody-mediated penetration of coronaviruses through tissue barriers or development of ADE. Viral protein immunogenicity, epitope mapping, the affinity of various antibodies, and the variability of the amino acid sequence in the region of a number of epitopes are being studied in detail; these factors can weaken the specificity of the antibodies produced and, as a consequence, weaken antiviral immunity (43-45). Recently published results indicate the importance and relevance of these studies (46).

IgA molecules predominate the secretions of most mucous membranes including the intestinal mucosa; these are synthesized by immune cells in the lamina propria, after which the polymeric immunoglobulin receptor ( $\operatorname{IgR}$ ) binds $\operatorname{IgA}$ dimers on the basolateral membrane of epithelial cells and promotes IgA transcytosis towards the apical membranes. In a similar way, pIgR carries out transcytosis of IgM pentamers, the function of which is like IgA, but the relative amount in mucous membrane secretions is significantly less. On the apical membrane surface or intracellularly during transcytosis, pIgR undergoes proteolytic cleavage, and its extracellular domain in complex with IgA or IgM is separated from the membrane (47). However, one group reported that the cleavage half-time of $\mathrm{pIgR}$ on the surface of the apical membrane is $5-10 \mathrm{~min}$, so intact pIgR molecules remain on the membrane (48). In polarized MDCK cells transfected with human pIgR, endocytosis of the pIgR ligand together with the receptor on the apical membrane was possible; however, this complex predominantly recirculated back to the apical membrane or remained inside the cell, and only $5 \%$ of the internalized pIgR complexes with the ligand entered the basolateral compartment over $90 \mathrm{~min}$ (48). Probably, due to the low level of pIgR transcytosis in MDCK model, this receptor should not play a significant role in the penetration of SARSCoV-2 through the cell barriers. It remains unclear whether the direction of IgA and IgM transport in polarized cells can be changed during SARS-CoV-2 infection. It is also unclear whether IgA and IgM complexes with antigens significantly contribute to coronavirus penetration through epithelial barriers by increasing transport from the apical to basolateral membrane. In Peyer's patches in the intestinal epithelium, there are so-called M-cells that are able to bind secretory IgA ( $\operatorname{IgA}$ ) in combination with antigens and transport them towards the basolateral membrane for immune cell presentation, but the sIgA receptor in these cells remains undefined (49). At the same time, M-cells remain a possible gateway for SARS-CoV-2 to penetrate the intestinal epithelial barrier.

Another class of antibodies present in mucous membranes secretions is IgG. In lower respiratory tract and genitourinary system secretions, IgG predominates over $\operatorname{IgA}$, and in the mucous membrane of the gastrointestinal tract, upper respiratory tract, and other areas, IgG levels can significantly increase in response to infection (47). Recognition of IgG Fc regions can occur with the involvement of Fc $\gamma \mathrm{R}$ and FcRn receptors. Fc $\gamma \mathrm{R}$ family receptors include three classes (I, II, and III); however, they are predominantly expressed on immune cells (50) and therefore do not play a special role in IgG transcytosis across epithelial barriers.

The FcRn molecule is a heterodimer of two subunits linked by non-covalent bonds. The p51 subunit, or $40-\mathrm{kDa}$ heavy $\alpha$-chain, is encoded by the FCGRT gene and directly interacts with the Fc region of $\mathrm{IgG}$; the $12-\mathrm{kDa}$ p14 subunit is a $\beta 2$-microglobulin encoded by the $B 2 M$ gene. The heavy $\alpha$-chain has three extracellular domains ( $\alpha 1, \alpha 2$, and $\alpha 3)$, a transmembrane domain, and a cytoplasmic tail of 44 amino acids (40). FcRn can bind with high affinity to the Fc region of $\mathrm{IgG}$ in weakly acidic conditions ( $\mathrm{pH}$ 5.0-6.5); at neutral $\mathrm{pH}$, weak binding was found only to IgG3 allotypes (51). At the same time, IgG3 appears at the earliest stages of viral infection and has the most pronounced effector activity, which contributes to the rapid development of a powerful immune response during infection, but it can lead to hyperreactivity and stimulate immune-mediated damage to one's own tissues (52). IgG3 also contributes to $\mathrm{ADE}$ of infection with the enveloped Dengue virus and Ebola virus (52).

According to the methodology (53) we have analyzed expression profiles of FCGRT and B2M in human tissues from 11 different organs based on RNA sequencing within the framework of The Cancer Genome Atlas project. We have also analyzed the gene expression levels of NRP1 and NRP2, which were shown to interact with furin-cleaved S-proteins, and ACE2 and TMPRSS2, which are considered the main participants in SARS-CoV-2 cell entry. High expression levels of FCGRT and $B 2 M$ were observed in the gastrointestinal tract organs and lungs, and expression levels were significantly higher than for NRP1, NRP2, ACE2, and TMPRSS2. This may indicate the possibility of antibody-dependent penetration of coronaviruses through organ barrier tissues. High FCGRT and B2M expression were also noted in the liver, which may indicate a potential mechanism of the liver damage observed in a number of COVID-19 patients (54).

\section{CORONAVIRUS ENDOCYTOSIS}

After binding to the cell surface, viruses can be endocytosed into the cell. The endocytosis of quantum dots coated with the SARSCoV-2 S-protein in complex with ACE2 molecules with attached $\mathrm{C}$-terminal green fluorescent protein was monitored in HEK293T cells using inclined/total internal reflection fluorescence illumination microscopy. Binding of quantum dots to ACE2 receptors on the cell surface and endocytosis into cells was detected within minutes, but this was suppressed by a dynamin inhibitor and neutralizing antibodies to ACE2, which may indicate a clathrin-mediated endocytosis mechanism (55). Lentivirus pseudotyped with SARS-CoV-2 S-protein engaged with the plasma membrane and entered the cell by 
clathrin-mediated endocytosis, and knockdown of clathrin heavy chain reduced viral infectivity (56).

The cytoplasmic tail of the ACE2 molecule contains a class I PSD-95/Dlg/ZO-1 (PDZ) binding motif, an endocytic motif for the clathrin-adaptor subunit AP2 $\mu 2$, and an LC3-interacting region motif (57). The class I PDZ binding motif in the ACE2 cytoplasmic tail binds the first PDZ-domain of the scaffold protein NHERF3, and the clathrin-adaptor subunit AP2 $\mu 2$ interacts with an endocytic motif in the ACE2 with low affinity; this interaction is abolished by Tyr781 phosphorylation (58), which indicates a potential mechanism of involvement in clathrin-mediated endocytosis. The LC3-interacting region motif mediates the interaction with the ATG8 domain containing microtubule associated protein 1 light chain 3 (MAP1LC3) proteins and GABA type A receptor-associated protein (GABARAP) in the phagophore membrane (59), suggesting the possibility of autophagy mechanisms following ACE2-dependent endocytosis. It was previously shown that upon binding to ACE2, SARS-CoV also enters the cell via clathrin-mediated endocytosis; however, the degree of clathrin-mediated endocytosis was not affected in cells expressing modified ACE2 without a cytoplasmic tail (60). The possibility of clathrin- and caveolin-independent endocytosis of SARS-CoV after ACE2 interaction was also demonstrated (61). Collectively, it indicates the need for additional research to clarify the mechanisms of endocytosis of coronaviruses after interaction with ACE2.

As was mentioned above, NRP1 can also serve as a SARSCoV-2 receptor $(37,38)$, which suggests additional endocytosis mechanisms. NRP1 binds molecules with a C-terminal, basic sequence motif (C-end Rule or CendR motif). It was shown that CendR-associated endocytosis is not clathrin- and caveolaemediated (62). Moreover, ultrastructurally this type of endocytosis resembles macropinocytosis but is mechanistically different. Specifically, it is receptor-associated and not inhibited by Cdc42 or Rac1 knockdown and weakly decreases when the macropinocytosis inhibitor rottlerin is used (62). NRP1 contains a PDZ binding motif that interacts with the PDZ-domain of the cytoplasmic protein GIPC1/synectin to play a role in trafficking endocytosed VEGFR2 into Rab5a-positive endosomes (63). NRP1-GIPC1/synectin interaction is not needed for CendR peptide binding, but it is important for cellular internalization and is enhanced by rapamycin treatment and depleting glucose or amino acids in the culture media through inhibition of the mammalian target of rapamycin pathway (62). However, during NRP1-associated endocytosis cargo ends up in endosomes and multivesicular bodies (62); therefore, despite the type of virus endocytosis, potential pathways for further intracellular sorting may intersect.

In addition to the specific mechanism of cell entry via a receptor molecule, there is also the possibility of endocytosis of opsonized viral particles that occurs due to interaction of $\mathrm{Fc}$ regions of antibodies on the surface of the virus with $\mathrm{Fc}$ receptors of target cells. Since Fc receptors are highly expressed on immune cells, a large number of studies have been devoted to the study of ADE in the context of immune cell infection. Passive immunization of cats with antibodies to the feline infectious peritonitis virus belonging to the coronavirus family can lead to $\mathrm{ADE}$, and in vitro antibodies to this virus cause antibodydependent infection of macrophages while maintaining virus activity (64). Antibodies to SARS-CoV promoted the infection of monocytes and B-line lymphoblasts mediated by Fc $\gamma \mathrm{R}$ and was independent of ACE2 receptor expression, $\mathrm{pH}$ level, and cysteine protease activity (65). Antibodies to SARS-CoV led to viral penetration into human macrophages with the participation of Fc $\gamma \mathrm{R}$-in particular Fc $\gamma$ RIIA and Fc $\gamma R$ RIB - with the synthesis of a structural viral $\mathrm{N}$-protein; however, the virus did not replicate productively, and the immune cells did not release new viral particles (66). When diluted 10 times, the anti-sera of patients recovered from SARS-CoV infection had an in vitro antiviral effect when infecting the monocytic cell line HL-CZ, but dilution of the anti-sera by 100,1000 , and 2000 times increasingly enhanced infection (67). In addition, during the development of antibodies to S- and N-proteins SARS-CoV in mice, infection enhancement was achieved due to antibodies to $S$ protein. The authors found that mouse anti-spike protein serum significantly reduced HL-CZ cell infection when diluted 10 times and markedly enhanced infection when diluted 1000 and 2000 times (67).

The S230 antibody to the receptor-binding domain of SARS$\mathrm{CoV} S$ protein prevented interaction of the virus with ACE2 but stimulated transition of the $S$ protein to the postfusion conformation, mimicking the interaction with ACE2, while the LCA60 antibody to the side of the receptor-binding domain of MERS-CoV S protein prevented interaction with DPP4 and stabilized the prefusion conformation (17). Interaction of MERS-CoV S-protein with antibodies to the receptor-binding domain can facilitate viral particle fusion with cells, mimicking the interaction with DPP4 (39). Antibodies to a specific epitope of the SARS-CoV S-protein caused ADE both in vitro in Vero E6 cells and in vivo in monkeys (68). Vaccination of monkeys with a modified vaccinia Ankara virus encoding full-length SARS-CoV spike glycoprotein and their subsequent infection with SARS-CoV resulted in a significantly lower viral load after vaccination. However, IgG-associated acute lung injury developed due to pro-inflammatory macrophage activation, which decreased upon Fc $\gamma$ R blockade (69). Apparently, a suboptimal immune response can lead to ADE and cytokine release syndrome, aggravating the course of infection (70-73). Antibodies to coronaviruses can stimulate viral particle endocytosis into cells expressing Fc receptors. The ultimate fate of the virus in the cell is determined both by the type of receptor and intracellular transport pathway, as well as the antigenic specificity and affinity of the bound antibody. Taken together, these factors determine the possibility of fusion of the viral and intracellular organelle membranes or exocytosis and transcytosis of the viral particle.

\section{CORONAVIRUS TRANSCYTOSIS}

Transcytosis is the transport of macromolecules, supramolecular complexes, and even microorganisms through the cell using 
membrane-bounded carriers. As a rule, the process is characteristic of polarized cells that form tissue barriers between two environments. Transcytosis can be carried out using various mechanisms; for example, one of the variants can be considered as a branch of endocytosis when the transported molecules are internalized using receptordependent mechanisms. This occurs most often through clathrin-coated vesicles; they enter the sorting membrane compartments of cells and then are released from cells by exocytosis, which is more typical for intestinal cells. Another variant, more typical for endothelial cells, is dependent on caveolae and a more direct route of transcytosis without entering intermediate compartments (74). It seems that viruses can use both types of transcytosis, which will be discussed later in this review.

Virus transcytosis through polarized cells can begin both with endocytosis upon binding to a specific target molecule and with macropinocytosis or phagocytosis. The main transcytosis pathway through the vascular endothelium of the lungs is predominantly caveolae dependent (75), and equine encephalitis viruses also penetrate the blood-brain barrier via caveolae-mediated transcytosis (76). Human immunodeficiency virus (HIV) can penetrate through the epithelial barriers in models of the endometrium (cell line HEC-1) and intestine (cell lines Caco-2, HT-29 and I407) by transcytosis without infecting the cells, but the presence of neutralizing $\operatorname{sIgA}$ and IgG disrupts transcytosis (77). Epstein-Barr virus from the herpesvirus family penetrates the polarized epithelium of the oral cavity using transcytosis, while an inhibitor of micropinocytosis (amiloride) reduced the degree of transcytosis (78). Caco-2 cells cultured in the presence of human lymphocytes from Peyer's patches acquired the M-cell phenotype and became capable of transcytosis from the apical to the basolateral membrane, even for large microorganisms such as Vibrio cholerae (79).

It is likely that intestinal epithelium and M-cells can carry out virion transcytosis through common recycling endosomes (Figure 1, left) after binding of SARS-CoV-2 to ACE2 and cleavage of the receptor with cellular proteases such as TMPRSS2 (34, 35). At the same time, the cell entry mechanism of coronaviruses suggests that after common recycling endosomes, SARS-CoV-2 is more likely to end up in the multivesicular bodies/late endosomes, and after fusion with the lysosome, cathepsins trigger fusion of the virus envelope with the endolysosome membrane and cytoplasmic release of the virus genetic material (80). Although a number of randomized controlled trials have shown that hydroxychloroquine is not an effective drug for post-exposure prophylaxis (81) or treatment (82) of COVID-19, several studies are still underway to prevent and treat COVID-19 with chloroquine and hydroxychloroquine (42). It is assumed that these drugs stabilize lysosomal membranes and prevent acidification of the late endosome environment $(42,83)$. This may increase the likelihood that multivesicular bodies merge with the basolateral membrane and that the luminal contents, including viruses, will be thrown into the extracellular space (84) (Figure 1, left).
There is also a potential variant of viral transcytosis when exocytosed viral particles are enclosed in membrane vesicles. One possible mechanism for this phenomenon is involvement of the autophagy process (Figure 1, right). It was already mentioned that ACE2's cytoplasmic tail has an LC3-interacting region motif that can determine interaction with the phagophore and autophagosome $(57,59)$. Inhibition of the autophagosomelysosome fusion can create conditions that promote fusion of the autophagosome outer membrane with the cytoplasmic membrane and subsequent release of the inner membrane and its contents into the extracellular space (85). This process can be enhanced by inhibiting lysosomal degradation with inhibitors of lysosomal acidification (85) or by other pathological processes that can promote exocytosis of the inner membrane of the autophagosome. In addition, the LC3 protein that plays a central role in autophagy was localized in exosomes produced by multivesicular bodies (86). This raises the possibility of fusion between autophagosomes and multivesicular bodies with release of the inner membrane structures of autophagosomes in the form of extracellular vesicles.

The possibility of including virions into autophagosomes and subsequent release from cells in membrane vesicles has been shown for non-enveloped picornaviruses such as poliovirus, rhinoviruses, and Coxsackie type B virus (87-89). Some herpesviruses such as varicella-zoster and Epstein-Barr are able to use the autophagosome membranes and prevent their fusion with lysosomes, enabling them to form envelopes when released from the cell (90-92). Influenza A and parainfluenza viruses can block the fusion of autophagosomes with lysosomes, redirecting the autophagosome membranes to the viral budding site of the cytoplasmic membrane (93-95). RNA-containing flaviviruses such as hepatitis C, Dengue, and Chikungunya viruses can use autophagosome membranes for exocytosis from cells using multivesicular bodies (96-99). The mouse hepatitis virus (MHV) from the coronavirus family stimulates the formation of double-membrane structures similar to autophagosomes, and its replication apparatus colocalizes with these structures (100). The SARS-CoV replication apparatus also colocalizes with autophagosome membranes (101). SARS-CoV and MERS-CoV can stimulate autophagosome formation but at the same time block their fusion with lysosomes $(102,103)$. SARS-CoV-2 is also able to limit the fusion of autophagosomes with lysosomes (104). As for the other viruses listed above, this may contribute to the release of SARS-CoV-2 particles or their elements from the cell in autophagosome membranes (Figure 1, right).

In human hepatoma cell culture infected with hepatitis $\mathrm{C}$ virus, extracellular vesicles contain virions and can infect healthy cells (105). Hepatitis A virus can also be secreted from human cells in extracellular vesicles. In Caco- 2 cells, this form of the virus is mainly secreted from the apical membrane $(<1 \%$ from the basolateral membrane); in HepG2-N6 cells, $36 \%$ and $64 \%$ of viruses are shed from the apical and basolateral sides, respectively (106). The possibility of transcytosis through human cells without infecting them was shown for HIV, while the viral particles or parts of them got into multivesicular bodies and were released in extracellular vesicles capable of infecting 


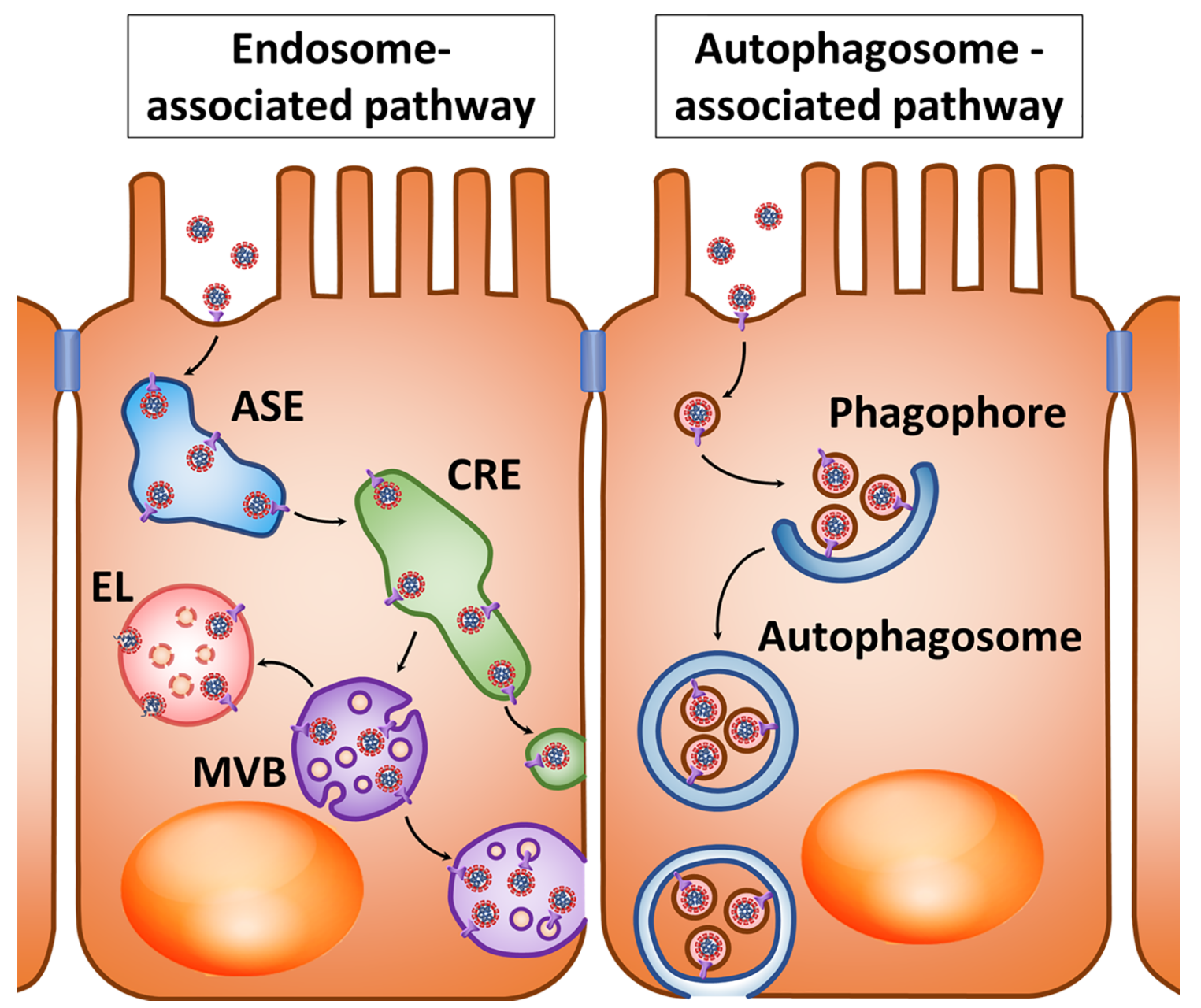

FIGURE 1 | Hypothetical pathways for SARS-CoV-2 transcytosis after interaction with ACE2. Left: After interacting with ACE2, virions enter the apical sorting endosome (ASE) and next common recycling endosome (CRE), from where they can be directed into vesicles either to the basolateral membrane or multivesicular bodies (MVBs). When an MVB fuses with lysosomes, endolysosome (EL) is formed; however, disruption of this process may promote the fusion of virion-containing MVB with the cytoplasmic membrane. Right: the presence of an LC3-interacting region motif in the cytoplasmic tail of ACE2 may suggest interaction of vesicles with virions with the phagophore and their accumulation in the autophagosome. Factors that prevent the fusion of autophagosomes with lysosomes create conditions for their fusion with the cytoplasmic membrane.

surrounding healthy cells (107-109). Apparently, preventing the fusion of autophagosomes and multivesicular bodies with lysosomes and the release of viruses from the cell in the membrane envelopes most often requires infection of the host cell. However, it is possible that during autophagy, endosomes or transport membrane vesicles with coronavirus particles can be captured in forming autophagosomes, and stabilization of lysosomes and autophagosomes will facilitate the release of the autophagosome contents, including viruses, to the extracellular space without infecting the cell itself (Figure 1, right). It is assumed that viral use of extracellular vesicles allows them to avoid the body's immune system and contributes to more effective infection because these vesicles are absorbed by other cells without having to bind to specific virus receptors (110). It is possible that coronaviruses including SARS-CoV-2 can undergo transcytosis across epithelial barriers while in extracellular vesicles.

In addition to endocytosis of opsonized viral particles into immune cells, viral endocytosis and transcytosis across tissue barriers by $\mathrm{Fc}$ receptor-expressing cells are also possible. Transcytosis across tissue barriers has been shown for enveloped viruses. In low $\mathrm{pH}$ conditions, HIV coated with specific antibodies can penetrate the epithelial layer of the genital tract mucosa via the $\mathrm{FcRn}$ molecule, the $\mathrm{Fc}$ receptor of IgG (111). Similarly, cytomegalovirus can be transported across the syncytiotrophoblast of the placental barrier. With a high titer of neutralizing antibodies, no infection develops in cytotrophoblast cells after transcytosis; however, medium and low levels of neutralizing antibodies, as well as antibodies with low neutralizing activity, can lead to infection (112). FcRn has 
been shown to be capable of transcytosis of antibody-antigen complexes across the intestinal barrier in vitro and in vivo (113). Interestingly, $\mathrm{ADE}$ in $\mathrm{HIV}$ infection may be associated with simultaneous interaction of the opsonized virus with $\mathrm{Fc} \gamma \mathrm{R}$ and the CD4 molecule, which is the cell target for HIV infection (114). In this regard, it can be assumed that SARS-CoV-2 may also undergo endocytosis and transcytosis due to antibodydependent interaction with Ig receptors, but this does not preclude the possibility of simultaneous interaction with ACE2.

Radioactively labeled ${ }^{125} \mathrm{I}-\mathrm{S} 1$ protein is transported across the mouse blood-brain barrier, and this process was enhanced by wheatgerm agglutinin suggesting adsorptive mechanism of S1 protein transcytosis connected with cell-surface glycoproteins that contain sialic acid or $\mathrm{N}$-acetylglucosamine (115). Authors speculate that if the viral binding protein crosses the blood-brain barrier, it is likely that protein enables the virus to cross the blood-brain barrier as well (115). This assumption is consistent with the detection of SARS-CoV-2 in the cerebrospinal fluid, although neuronal retrograde dissemination is also possible route of the nervous system invasion (116).

Syncytiotrophoblast of placental barrier can be infected by SARS-CoV-2 which was confirmed by molecular and immunohistochemical assays and electron microscopy. Authors observed high maternal serum titers of anti-S-protein antibodies and suggested that potential mechanism of placental invasion in this case would be antibody-dependent transcytosis mediated by FcRn (117). Another report also confirmed placental syncytiotrophoblast SARS-CoV-2 invasion by electron microscopy (118). Positive anti-SARS-CoV-2 IgM in blood of newborns delivered by cesarian from mothers infected with SARS-CoV-2 suggest in utero exposure to the SARS-CoV-2 virus $(119,120)$. In addition to infection of the placenta, the mechanism of vertical virus transmission can be due to the transcytosis of opsonized or free viruses or the transfer of viruses by infected blood cells, but more clinical and experimental studies are required to confirm these mechanisms (121).

Obviously, the fate of antibody-antigen complexes on the surface of epithelial barriers, including opsonized viral particles, depends on the properties of antibodies and the density and transport mechanisms of the corresponding antibody receptors in the target cell. All Ig types including $\operatorname{IgA}, \operatorname{IgD}, \operatorname{IgE}, \operatorname{IgG}$, and IgM are found in mucous membrane secretions, but their ratio, structure, and biological properties differ from those in blood plasma. The IgA, IgM, and IgG classes play the main role in antiviral immunity (122).

\section{CORONAVIRUS PARACELLULAR TRAFFICKING}

Another potential mechanism for viruses to cross tissue barriers is paracellular trafficking. HIV-1 infection compromises the blood-brain barrier integrity by decreasing the expression of tight junction proteins, extracellular matrix disruption by metallopeptidases, and inflammation (123). Rotavirus infection disrupts tight junctions in the intestinal epithelium and Caco-2 monolayer (124). The tight junction proteins JAM-A, occludin, and ZO-1 play an important role during rotavirus entry into MA104 cells (125). Hepatitis C virus binds to occludin and claudin-1 as tight junction-associated coreceptors to enter the cell (126). Human papilloma virus deregulates $\beta$-catenin and $\mathrm{ZO}-1$ expression in adherent and tight junctions respectively potentially disrupting the cellular barrier (127). Rotaviruses and reoviruses disrupt intercellular junctions to access their receptors on the basolateral membrane $(128,129)$. West Nile and dengue viruses modify the structure of tight junctions to enter the bloodstream $(130,131)$.

PDZ domains have different cellular functions including protein transport and metabolism, cell-cell communication, and cell polarization (132). PDZ-binding motifs were discovered in proteins of different viruses, such as human $\mathrm{T}$ lymphotropic virus type 1, human papilloma virus, human adenovirus type 9 , hepatitis $B$ and $C$ viruses, Kaposi sarcoma herpesvirus, human immunodeficiency virus, providing interaction with PDZ-domain-containing proteins and enhancing viral replication, dissemination, and immune system evasion (132-134). SARS-CoV and SARS-CoV-2 E-proteins also have PDZ-binding motif (135). It is proposed that the interaction of SARS-CoV-1 E-protein with PALS1, the protein of an apical cell polarity complex, recruits PALS1 to the site of virus assembly, possibly disrupting intercellular tight junctions and increasing epithelial permeability for virions (136). E-proteins also interact with tight junction protein ZO-1 (137), adhesion junction protein syntetin (138), and other cell junction proteins (139). The redistribution of these molecules might contribute to cell junction impairment in lung epithelium and vessels during SARS-CoV-2 infection (135). The SARS-CoV-2 S-protein alters blood-brain barrier function both in $2 \mathrm{D}$ static and $3 \mathrm{D}$ microfluidic models (140). SARS-CoV-2 infection of in vitro cultured polarized human airway epithelium leads to dispersed ZO-1 expression without clear tight junctions (141).

\section{USING TISSUE BARRIER MODELS TO STUDY CORONAVIRUS TRANSCYTOSIS}

Due to the economic and social effects of COVID-19, it is highly relevant to study the mechanisms of infection and search for new effective drugs capable of fighting coronaviruses. Since animal studies are lengthy and often do not yield results when specific pathogens are studied or when the studied drugs use specific features of human biology, animal-free approaches including in vitro studies using microfluidic technologies and various cell models based on organoids consisting of human cell lines (142144) are increasingly important.

Explant cultures can be used as organ models for viral infection research because they reproduce natural morphology and microenvironment of organs. However, such models have low availability due to insufficient donor material, short viability, and low reproducibility of research results (145).

The human adenocarcinoma cell line Caco-2 is successfully used as a model of the human intestinal barrier. During long- 
term cultivation, Caco- 2 cells polarize, form microvilli, tight junctions, extracellular matrix, and begin to express specific enterocyte markers (146-148). Models based on Caco-2 cells using microfluidic devices that create medium flow make the model even closer to the physiological conditions of human intestine (149-151). The lung-on-chip model in a microfluidic device can be used to study influenza A virus cell entry, replication, virulence of different strains, cytokine production by host cells, and circulating immune cell recruitment (152). The same model was used to study the effect of seven clinically approved drugs on the entry of virus-like particles with SARSCoV-2 S-protein, and differences in drug effects were noted compared to the cell model outside the microfluidic chip (152). It can be assumed that the gut-on-a-chip model based on Caco-2 cells will also differ from cells in a static culture medium.

In an intestinal model based on Caco- 2 cells, SARS-CoV-2 infection depends on ACE2 and TMPRSS2 (6). A study of 13 human cell lines showed that only Caco-2 had sufficient ACE2 expression and was susceptible to SARS-CoV infection in vitro (153). Among seven other human colorectal adenocarcinoma cell lines (DLD-1, HCT-116, HT-29, LoVo, LS-180, SW-480, and SW-620) only LoVo cells were susceptible to SARS-CoV infection, but this did not correlate with ACE2 gene expression, which was higher in LS-180 and SW-620 by about 7 and 50 times, respectively (154). In another study, among colorectal adenocarcinoma cell lines Caco-2, CL-14, HT-29, SW-480, DLD-1, and HCT-15 only Caco-2 and CL-14 were susceptible to SARS-CoV (155).

According to a study of the proteome of filter-grown Caco-2 cells (156), there are $\sim 1.7 \times 10^{5}$ copies of the p51 FcRn subunit and $\sim 1.5 \times 10^{6}$ copies of $\beta 2$-microglobulin in each Caco- 2 cell. Considering that the same study reported $\sim 2.0 \times 10^{4}$ ACE2 molecules and $\sim 2.7 \times 10^{4} \mathrm{NRP} 2$ molecules per Caco- 2 cell, while NRP1 was not detected, cell entry of opsonized virion through the antibody complex with FcRn may be highly probable. It was previously shown that infection with the porcine transmissible gastroenteritis virus (TGEV) belonging to the coronavirus family can cause an increase of FcRn expression in the normal porcine intestinal cell line IPEC-J2 by activating NF- $\kappa \mathrm{B}$ signaling through membrane receptors of the Toll-like receptor family and increasing pro-inflammatory cytokine levels $(157,158)$. Conversely, infection with the CHNJS-2017 strain of porcine deltacoronavirus PDCoV in piglets was associated with NF- $\kappa \mathrm{B}$ pathway suppression and decreased FcRn and $\mathrm{pIgR}$ expression in the intestinal epithelium, which may enable the virus to avoid secreted neutralizing antibodies (159). Thus, SARS-CoV and SARS-CoV-2 infection can both theoretically increase FcRn and pIgR expression and antibodymediated virus transcytosis across the intestinal barrier.

We previously published the results of a transcriptome study using Affymetrix Human Gene 1.0 ST Arrays (GSE81867) for Caco-2 cells grown either on Transwell culture inserts in static medium or on a microfluidic chip with culture medium circulation $(150,151)$. Further transcriptome analyses revealed high FCGRT gene expression in differentiated Caco-2 for both conditions. At the same time, the expressions of ACE2, PIGR,
$N R P 1$, and NRP2 genes in these cells were significantly lower. This is consistent with the proteome data of Caco-2 cells, in that ACE2 and NRP2 levels were significantly lower than FCGRT level, while pIgR and NRP1 were not detected (156).

Song et al. investigated the intracellular transport of micelles with a size of $30-40 \mathrm{~nm}$, coated with FcBP, the peptide ligand of FcRn (160). These micelles may mimic SARS-CoV-2 virions covered with immunoglobulins because both of them have Fc regions on their surface, therefore it is reasonable to assume that the intracellular transport pathways of FcBP-decorated micelles may be a model of opsonized coronavirus particle transport. The analysis of micelle transport pathways in Caco- 2 cells revealed their inclusion in the pathways of recirculation and transcytosis through common recycling endosomes and the endoplasmic reticulum, but not the Golgi complex (160). Macropinocytosis inhibitors 5-(N-ethyl-N-isopropyl)-amiloride (EIPA) and cytochalasin $\mathrm{D}$, as well as the tyrosine-specific protein kinase inhibitor genistein had no effect on FcRn-mediated transport. Dynasore, which inhibits dynamin-dependent clathrin vesicle formation during endocytosis and disrupts lipid raft structure, reduced FcRn-mediated micelle uptake by $20 \%$. Hypertonic sucrose solution that prevents clathrin vesicle formation also significantly suppressed micelle uptake, while chlorpromazine, which inhibits AP2 subunit assembly during clathrin-mediated endocytosis, had practically no effect on FcRn-mediated uptake. When analyzed using transport inhibitors associated with caveolae and lipid rafts, the results revealed that filipin slightly increased FcRn-mediated micelle uptake, nystatin slightly decreased it, and methyl- $\beta$-cyclodextrin significantly inhibited FcRn-mediated uptake. Thus, it was concluded that FcRnmediated endocytosis can be simultaneously associated with both clathrin-coated vesicles and caveolae and lipid rafts (160).

Analysis of the transport pathways of FcBP-decorated micelles revealed that they are only weakly retained in apical sorting endosomes, actively pass through common recycling endosomes during transcytosis toward the basolateral membrane, are partially transported to the apical recycling endosomes and endoplasmic reticulum to return to the apical membrane, but are not transported through the Golgi complex and practically do not enter basal recycling endosomes as this compartment is associated with basolateral membrane endocytosis. At a relatively low FcRn ligand density, micelles were successfully avoided late endosomes and did not fuse with lysosomes; however, this pathway significantly increased at a high ligand density (160).

The described transport mechanisms suggest that Ig-coated SARS-CoV-2 may undergo transcytosis across the intestinal barrier and other tissue barriers whose cells express FcRn, and with a high level of antibodies increased transport to late endosomes and fusion with lysosomes can be expected. However, it has already been mentioned that the use of lysosome lumen acidification inhibitors can lead to multivesicular bodies merging with the basolateral membrane to promote viral transcytosis (Figure 2, right).

The polarity of transcytosis involving FcRn deserves special consideration in light of the potential for infection with 


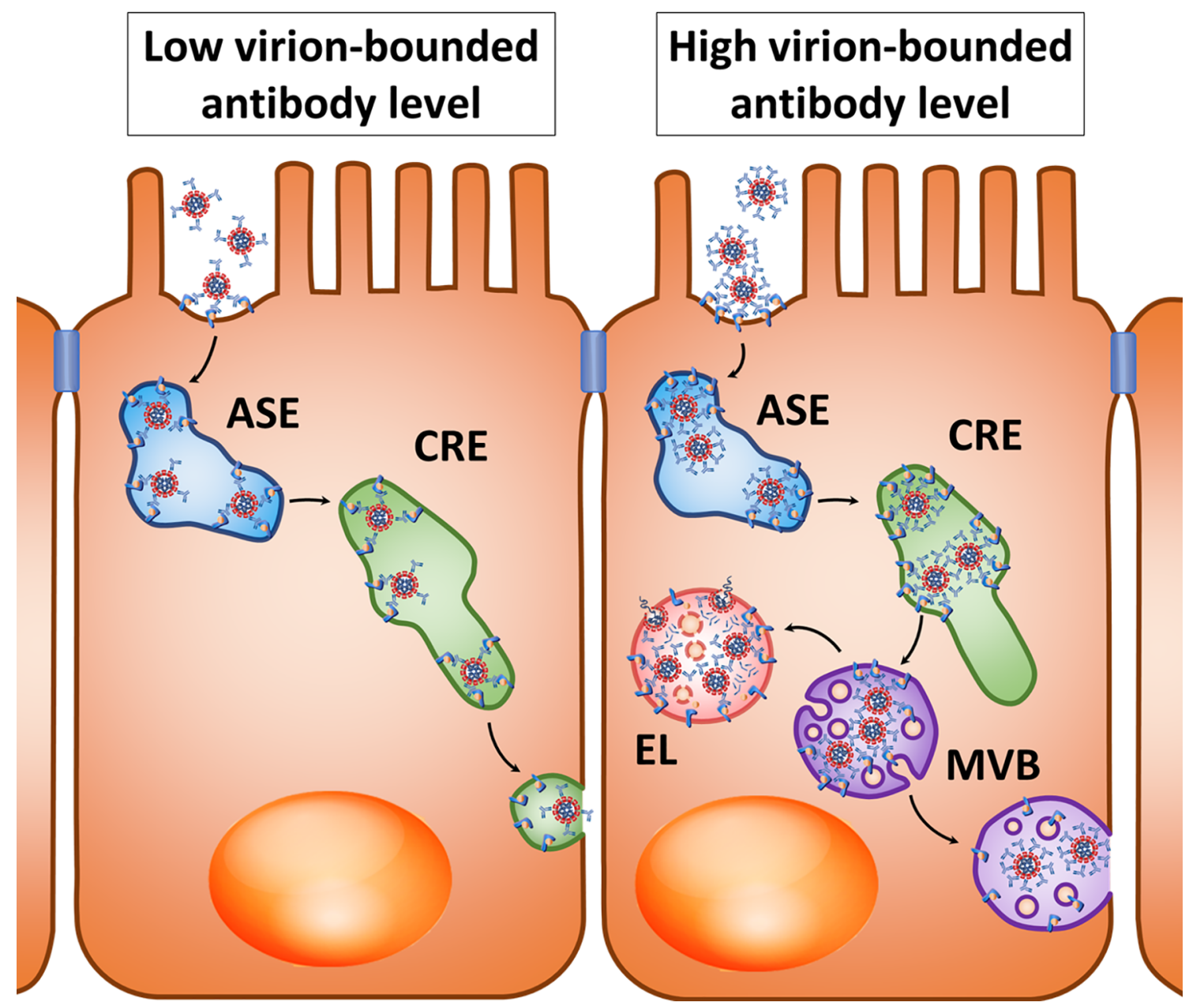

FIGURE 2 | Hypothetical pathways for transcytosis of the opsonized SARS-CoV-2 after interaction with the FcRn, Fc-region receptor in a polarized cell. Left: At a relatively low virion-bounded antibody level, coronavirus transcytosis is possible through the tubules of apical sorting endosome (ASE) and common recycling endosome (CRE). Right: With a high density of virion-bounded antibodies or virion agglomerate formation, sorting in CRE may be changed, resulting in virions entering the multivesicular bodies (MVBs) that can either fuse with lysosomes to form endolysosome (EL), or fuse with the cytoplasmic membrane when lysosome fusion is suppressed.

coronaviruses involving this receptor. It was shown that Caco-2 cells transfected with the murine Ceacaml gene, which is a receptor of $\mathrm{MHV}$, were successfully infected with this coronavirus, while the release of new viral particles occurred on the basolateral surface (161).

Within endothelial cells, FcRn is primarily localized in early endosomes positive for Rab5 and EEA1 and in recycling endosomes positive for Rab4 and Rab11 (162, 163). Ig molecules are believed to penetrate into endothelial cells mainly due to pinocytosis and bind to FcRn under conditions of low intracellular $\mathrm{pH}$, and they then undergo further sorting (40). During antigen opsonization involving large amounts of antibodies and "cross-linking" of several FcRn molecules by polymerized IgG, immune complexes in the endothelium are predominantly directed to lysosomes, while FcRn associated with monomeric Ig molecules allows the targeting of immune complexes in recycling endosomes (164). This is consistent with the previously mentioned results obtained in polarized Caco- 2 cells, in which the high density of the FcRn ligand on the surface of artificial micelles induced a decrease in transcytosis and increased sorting of these micelles into lysosomes compared with low ligand density (160). This may be explained by the fact that the high density of complexes of ligands and antibodies prevents penetration of opsonized particles into the narrow sorting channels of endosomes (165). Perhaps penetration into narrow sorting channels is hindered by the size of "cross-linked" immune complexes, as has been shown for sorting different sizes of cargoes in macrophages (166). Another possible cause is steric mismatch between cross-linked FcRn-IgG complexes to the large curvature of endosome-sorting tubules (167) (Figure 2, right).

The analysis of FcRn transcytosis in polarized cells was largely performed in MDCK II canine renal epithelial cells. The transcytosis mechanisms in these cells differed from the receptor recirculation mechanism: FcRn-mediated transcytosis 
occurred in both directions and depended on myosin $\mathrm{Vb}$ and GTPase Rab25, while FcRn recirculation depended on Rab11a and was only carried out in the direction of the basolateral membrane (168). Transcytosis was also dependent on the binding of calmodulin to the cytoplasmic tail of FcRn and required endosome medium acidification (40). When MDCK II cells were transfected with human FcRn, it predominantly localized in apical intracellular vesicular structures and the basolateral membrane, while removal of the cytoplasmic tail of FcRn containing the dileucine and tryptophan motifs of endocytosis led to receptor redistribution into the apical membrane. Endocytosis of full-length FcRn was carried out equally from the apical and basolateral sides. The authors concluded that the observed intracellular distribution of FcRn is associated with the predominant direction of transcytosis from the apical to basolateral cell surface, while maintaining the possibility of transcytosis in the opposite direction (169).

In a model of intestinal epithelium based on polarized cells of colorectal adenocarcinoma T84, FcRn was mainly intracellular and on the apical membrane of cells, with transcytosis involving FcRn proceeding in both directions (170). In human small intestine epithelial cells, the receptor was also localized predominantly apically (171). A study of polarized Caco-2 cells suggested that Ig endocytosis from the apical membrane may occur mainly due to pinocytosis rather than binding to the receptor, and binding to FcRn occurs in endosomes already inside the cell at a low $\mathrm{pH}$ (172). Others demonstrated that FcRn can transport monomeric IgG from the basolateral to apical membrane of intestinal cells and then transport Ig complexes with antigens in the opposite direction to present antigens as immune complexes to dendritic cells of the mucous (40). The immune complexes of antibodies and antigens could also be transported from the basolateral to apical membrane (113). These results suggest the possibility of SARS-CoV-2 transcytosis across epithelial barriers due to FcRn.

Models based on primary intestinal epithelial cells, small intestine explants, and intestinal organoids are susceptible to MERS-CoV infection and able to support sustainable virus replication. Caco-2 cells grown on Transwell culture inserts were more susceptible to MERS-CoV upon inoculation of the virus from the apical side than from the basolateral side, while inoculation of the virus into the stomach of a transgenic mouse expressing human DPP4 led to intestinal infection, spread of infection to the respiratory tract, and death (173).

Another promising tool to study SARS-CoV-2 infection is organoids, self-organized three-dimensional tissue or cell cultures representing miniaturized and simplified models of organs. Intestinal organoids derived from horseshoe bats and humans that can recapitulate intestinal mucosa were susceptible to SARS-CoV-2 infection and sustain viral replication (174). Human small intestinal organoids were readily infected by SARS-CoV and SARS-CoV-2 producing infectious viral particles (8). Remdesivir effectively inhibited SARS-CoV-2 infection in human intestinal organoids derived from pluripotent stem cells (175). Lung and intestine organoid models were used for high-throughput screening to identify
SARS-CoV-2 entry inhibitors (176). Human bronchial organoids consisting of basal, club, ciliated, and goblet cells were susceptible to SARS-CoV-2 infection and allow to study camostat inhibitory effect on virus entry (177). Cell and organoid derivatives from human pluripotent stem cells were incubated with Spike-enabled pseudo-entry virus to study SARS-CoV-2 tissue tropism. Pancreatic endocrine cells, liver organoids, cardiomyocytes, dopaminergic neurons, adult primary human islets, adult hepatocyte and cholangiocyte organoids were highly permissive to SARS-CoV-2 infection (178). Brain organoids provide a useful model for investigating SARS-CoV-2 entry into the human brain and elucidating the susceptibility of the brain to SARS-CoV-2 (179-181). Human induced pluripotent stem cell-derived BrainSphere model was used to show SARSCoV-2 infection of neural cells expressing ACE2 but not TMPRSS2, however authors do not model how viruses enter brain parenchyma (182). Induced pluripotent stem cells-derived human neural progenitor cells, neurospheres, and brain organoids were permissive to SARS-CoV-2 and showed signs of productive infection (183). SARS-CoV-2 can directly infect engineered human blood vessel organoids and human kidney organoids, which can be inhibited by soluble human ACE2 (184). It should be concluded that organoids make it possible to study the tropism of coronaviruses and to search for potential drugs against SAS-CoV-2; however, using these models, it is difficult to reproduce the penetration of viruses through barrier tissues.

The possibilities of using microfluidic kidney-on-a-chip (185) and lung-on-a-chip (186) models for studying acute kidney injury and lung infection, respectively, have been proposed but not used to study SARS-CoV-2. In the microfluidic model of the human blood-brain barrier, administration of different SARSCoV-2 S-protein subunits induced a pro-inflammatory response and impaired the model's barrier function (140). Models of human organs, including microfluidic platforms, have been used to study various viral infections $(187,188)$, which can be adapted and optimized to investigate coronavirus infections.

\section{POTENTIAL CLINICAL TARGETING OF SARS-CoV-2 BARRIER PENETRATION}

The possibility of SARS-CoV-2 hijacking the endocytosis and transcytosis mechanisms in barrier tissues makes it relevant to search for new inhibitors and modulators of these processes. Different endocytic pathways can be targeted in vitro by known pharmacological blockers such as amiloride for macropinocytosis, methyl- $\beta$-cyclodextrin for dynaminindependent endocytosis, nystatin for caveolae-mediated endocytosis, dynasore and pitstop for clathrin-dependent endocytosis (189). One of the main approaches for developing drugs against SARS-CoV-2 is the repurposing of previously approved drugs. As was mentioned above, there are several studies of chloroquine and hydroxychloroquine as SARS-CoV2 entry blockers through endosomal acidification, although their effectiveness is controversial. From previously approved drugs chlorpromazine, promethazine, and vinblastine can regulate 
clathrin-dependent endocytosis (190-192), fluvoxamine and sertraline affect dynamin-dependent endocytosis (193, 194), nystatin is used to block caveolae (190), and macropinocytosis can be targeted by amiloride, flubendazole, imipramine, itraconazole, terfenadine, and vinblastine $(195,196)$.

The ClinicalTrials.gov search revealed two clinical trials of chlorpromazine, seven trials of fluvoxamine, and two studies of itraconazole for COVID-19 treatment, details are summarized in Table 1. Other mentioned above drugs are not studied for COVID-19 treatment in clinical trials yet. Sertraline is studied only as a part of the usual treatment of post-traumatic stress disorder in COVID-19 survivors comparing to Basic Body Awareness Therapy (NCT04396314). One trial is aimed to study the pharmacokinetics, pharmacodynamics, and safety profile of understudied drugs including sertraline administered to children with COVID-19 and other conditions per standard of care (NCT04278404). There are no clinical trials studying amiloride as primary treatment for COVID-19, but it is one of many drugs for hypertension treatment in patients with COVID19 in the trial NCT04467931.

As was mentioned above, PDZ-binding motifs might play role in different viral infections. The human papilloma virus PDZdomain-containing protein E6 was targeted in different studies to prevent infection and oncogenic transformation of cervical epithelial cells. Therapeutic targeting of E6 started with peptide-based inhibition but these peptides had low affinity and weak activity in cancer cell lines (198). High-affinity bivalent binders of the E6 protein were designed by linking of its cellular PDZ-domain-containing targets, but their activity was studied only in vitro $(199,200)$. The complex of E6 PDZ-binding motif and PDZ domain was used to screen a commercial compound database revealing two potential regulators but experimental validation was not presented (201). In vitro study revealed the potential of fusicoccin to prevent interaction of the E6 PDZ-binding motif with 14-3-3 protein isoforms without in vivo validation (202).

There are also studies of drugs potentially preventing cell SARS-CoV-2 entry by TMPRSS2 protease regulation. TMPRSS2 inhibitors include camostat mesylate, nafamostat mesylate, and antiandrogens (203). There are 25 trials of camostat mesylate, 7 trials of nafamostat mesylate, 2 trials of enzalutamide, 6 trials of proxalutamide, 1 trial of dutasteride, 2 trials of enzalutamide, and 3 trials of bicalutamide on ClinicalTrials.gov. Another study revealed a novel potential SARS-CoV-2 entry route through host cell receptor CD147 and showed, that the anti-CD147 antibody, meplazumab, inhibits SARS-CoV-2 amplification in vitro (204). The Phase 1/Phase 2 clinical trial of meplazumab for treatment of COVID-19 is completed (NCT04275245) and Phase 2/Phase 3 trial is recruiting patients (NCT04586153). These trials were not the subject of this review as well as studies of angiotensin receptor blockers, calmodulin antagonists, selective oestrogen receptor modifiers, and recombinant soluble ACE2 as ACE2 modulators (203).

Currently, the expression of ACE2 is accounted critical for SARS-CoV-2 binding and entry. Nonetheless, it is important to identify new mechanisms that the virus may employ to its advantage for a complete pathogenic cycle, including endocytosis and transcytosis hijacking by SARS-CoV-2. As we mentioned above, several trials are studying potential inhibitors and modulators of endocytosis and transcytosis, but their results mostly have not been published yet.

\section{CONCLUSION}

Several studies suggest that the gastrointestinal tract may be an entry portal and reservoir for SARS-CoV-2 infection. Native SARS-CoV-2 virions have sparsely located highly mobile Sproteins on their surface, which enables active interaction with both specific target cell receptors and immunoglobulins. Native SARS-CoV-2 virions undergo endocytosis when S-proteins interact with ACE2 or NRP1 with the assistance of cellular proteases. Opsonized SARS-CoV-2 virions are coated with antibodies that mask viral proteins, but the virus can still bind the cell surface and be endocytosed due to the presence of receptors for antibody Fc regions. This normally promotes absorption of virions by immune cells for antigen presentation and pathogen neutralization; however, the phenomenon of $\mathrm{ADE}$ occurs when the concentration of antibodies is too low or they do not have sufficient specificity and neutralizing activity to prevent intracellular viral replication. ADE has been experimentally shown for the SARS-CoV, MERS-CoV, and SARS-CoV-2 coronaviruses, but the clinical feasibility of $\mathrm{ADE}$ in these infections remains unclear.

Epithelial cells of barrier tissues in the intestine, lungs, kidneys, and placental trophoblast express the IgG FcRn receptor, which mediates transcytosis of antigen-antibody complexes for immune cell presentation. At the same time, complexes of antigens with polymeric immunoglobulins (IgA and $\operatorname{IgM}$ ) and their receptor pIgR do not seem to be effectively transported across the epithelial barrier towards the basolateral membrane. However, IgG-dependent transcytosis of viral particles can allow enveloped viruses (e.g., HIV and cytomegalovirus) to penetrate barrier tissues. In this regard, the possibility of coronavirus penetration through the epithelial barrier of the intestine and other organs by an antibodydependent mechanism cannot be denied. This possibility is supported by the high level of FcRn receptor expression in the gastrointestinal tract and lungs. At the same time, the Caco- 2 cell line expressing ACE2 and FcRn and some other models in static culture medium and microfluidic devices can be used as suitable intestinal barrier models for studying coronavirus transcytosis. Another possible pathway for viruses to penetrate tissue barriers is paracellular trafficking via disruption or modulation of cell-cell junctions. SARS-CoV-2 E-protein has a PDZ-binding motif which could bind cell junction proteins and cause their redistribution from junctions to the site of virus assembly, leading to barrier impairment.

The repurposing of previously approved drugs that can target different endocytic pathways allows studying potential endocytosis and transcytosis inhibitors and modulators to fight COVID-19. There are several registered clinical trials of 
TABLE 1 | Clinical trials of potential endocytosis and transcytosis inhibitors and modulators.

\begin{tabular}{|c|c|c|c|c|c|c|c|}
\hline & Drug & $\begin{array}{l}\text { Regulated } \\
\text { endocytic } \\
\text { pathway }\end{array}$ & Clinical trials related to COVID-19 & Phase & Interventions & Status & $\begin{array}{l}\text { ClinicalTrials.gov } \\
\text { Identifier }\end{array}$ \\
\hline 1 & Chlorpromazine & Clathrin & $\begin{array}{l}\text { Repurposing of Chlorpromazine in Covid-19 } \\
\text { Treatment }\end{array}$ & $\begin{array}{l}\text { Phase } \\
3\end{array}$ & $\begin{array}{l}\text { Drug: } \\
\text { Chlorpromazine } \\
\text { Combination } \\
\text { Product: } \\
\text { Standard of } \\
\text { Care }\end{array}$ & Not yet recruiting & NCT04366739 \\
\hline 2 & Chlorpromazine & Clathrin & $\begin{array}{l}\text { Administration of Chlorpromazine as a } \\
\text { Treatment for COVID-19 }\end{array}$ & $\begin{array}{l}\text { Phase } \\
2 \\
\text { Phase } \\
3\end{array}$ & $\begin{array}{l}\text { Drug: } \\
\text { Chlorpromazine }\end{array}$ & Not yet recruiting & NCT04354805 \\
\hline 3 & Fluvoxamine & Dynamin & $\begin{array}{l}\text { Fluvoxamine Administration in Moderate } \\
\text { SARS-CoV-2 (COVID-19) Infected Patients }\end{array}$ & $\begin{array}{l}\text { Phase } \\
2\end{array}$ & $\begin{array}{l}\text { Drug: Placebo } \\
\text { Drug: } \\
\text { Fluvoxamine }\end{array}$ & Recruiting & NCT04718480 \\
\hline 4 & Fluvoxamine & Dynamin & $\begin{array}{l}\text { A Double-blind, Placebo-controlled Clinical } \\
\text { Trial of Fluvoxamine for Symptomatic } \\
\text { Individuals With COVID-19 Infection (STOP } \\
\text { COVID) }\end{array}$ & $\begin{array}{l}\text { Phase } \\
2\end{array}$ & $\begin{array}{l}\text { Drug: } \\
\text { Fluvoxamine } \\
\text { Drug: Placebo }\end{array}$ & $\begin{array}{l}\text { Completed: patients treated } \\
\text { with fluvoxamine, compared } \\
\text { with placebo, had a lower } \\
\text { likelihood of clinical } \\
\text { deterioration over } 15 \text { days } \\
\text { (197) }\end{array}$ & NCT04342663 \\
\hline 5 & Fluvoxamine & Dynamin & $\begin{array}{l}\text { Fluvoxamine for Early Treatment of Covid-19 } \\
\text { (Stop Covid 2) }\end{array}$ & $\begin{array}{l}\text { Phase } \\
3\end{array}$ & $\begin{array}{l}\text { Drug: } \\
\text { Fluvoxamine } \\
\text { Drug: Placebo }\end{array}$ & Active, not recruiting & NCT04668950 \\
\hline 6 & Fluvoxamine & Dynamin & $\begin{array}{l}\text { Fluvoxamine for Adults With Mild to Moderate } \\
\text { COVID-19 }\end{array}$ & $\begin{array}{l}\text { Phase } \\
2\end{array}$ & $\begin{array}{l}\text { Drug: } \\
\text { Fluvoxamine } \\
\text { Drug: Placebo }\end{array}$ & $\begin{array}{l}\text { Suspended (Closure of main } \\
\text { community treatment center) }\end{array}$ & NCT04711863 \\
\hline 7 & Fluvoxamine & Dynamin & $\begin{array}{l}\text { Outpatient Treatment of SARS-CoV-2 With } \\
\text { Ivermectin, Fluvoxamine, and Metformin } \\
\text { (COVID-19) }\end{array}$ & $\begin{array}{l}\text { Phase } \\
2 \\
\text { Phase } \\
3\end{array}$ & $\begin{array}{l}\text { Drug: } \\
\text { Metformin } \\
\text { Drug: Placebo } \\
\text { Drug: } \\
\text { Fluvoxamine } \\
\text { Drug: } \\
\text { Ivermectin }\end{array}$ & Recruiting & NCT04510194 \\
\hline 8 & Fluvoxamine & Dynamin & $\begin{array}{l}\text { Repurposed Approved and Under } \\
\text { Development Therapies for Patients With } \\
\text { Early-Onset COVID-19 and Mild Symptoms }\end{array}$ & $\begin{array}{l}\text { Phase } \\
3\end{array}$ & $\begin{array}{l}\text { Drug: } \\
\text { Fluvoxamine } \\
\text { Drug: } \\
\text { Doxazosin } \\
\text { Drug: } \\
\text { Ivermectin } \\
\text { Drug: Placebo } \\
\text { Drug: } \\
\text { Peginterferon } \\
\text { Lambda-1a } \\
\text { Drug: } \\
\text { Peginterferon } \\
\text { Beta-1A }\end{array}$ & Recruiting & NCT04727424 \\
\hline 9 & Fluvoxamine & Dynamin & $\begin{array}{l}\text { ACTIV-6: COVID-19 Study of Repurposed } \\
\text { Medications }\end{array}$ & $\begin{array}{l}\text { Phase } \\
3\end{array}$ & $\begin{array}{l}\text { Drug: } \\
\text { Ivermectin } \\
\text { Drug: } \\
\text { Fluvoxamine } \\
\text { Drug: } \\
\text { Fluticasone } \\
\text { Other: Placebo }\end{array}$ & Recruiting & NCT04885530 \\
\hline 10 & Itraconazole & Macropinocytosis & $\begin{array}{l}\text { Efficacy and Safety of Drug Combination } \\
\text { Therapy of Isotretinoin and Some Antifungal } \\
\text { Drugs as A Potential Aerosol Therapy for } \\
\text { COVID-19: An Innovative Therapeutic } \\
\text { Approach COVID-19 (Isotretinoin) }\end{array}$ & $\begin{array}{l}\text { Phase } \\
2\end{array}$ & $\begin{array}{l}\text { Drug: } \\
\text { Aerosolized } \\
\text { Isotretinoin plus } \\
\text { Aerosolized } \\
\text { Itraconazole } \\
\text { Drug: } \\
\text { Aerosolized } \\
\text { Isotretinoin }\end{array}$ & Not yet recruiting & NCT04577378 \\
\hline
\end{tabular}


TABLE 1 | Continued

\begin{tabular}{|c|c|c|c|c|c|c|}
\hline Drug & $\begin{array}{l}\text { Regulated } \\
\text { endocytic } \\
\text { pathway }\end{array}$ & Clinical trials related to COVID-19 & Phase & Interventions & Status & $\begin{array}{c}\text { ClinicalTrials.gov } \\
\text { Identifier }\end{array}$ \\
\hline 11 Itraconazole & Macropinocytosis & $\begin{array}{l}\text { Drug-Drug Interaction Study Assessing Effect } \\
\text { of Itraconazole on PF-07321332/Ritonavir in } \\
\text { Healthy Participants }\end{array}$ & $\begin{array}{l}\text { Phase } \\
1\end{array}$ & $\begin{array}{l}\text { Drug: PF- } \\
\text { 07321332/ } \\
\text { ritonavir } \\
\text { Drug: } \\
\text { Itraconazole }\end{array}$ & Recruiting & NCT04962022 \\
\hline
\end{tabular}

chlorpromazine, fluvoxamine, and itraconazole, but they lack published results, and more trials are needed to find new treatment modalities for COVID-19.

\section{FUTURE DIRECTIONS}

An increase in the number of people recovered from COVID-19 and the use of vaccines and convalescent plasma treatment suggests that we will increasingly encounter questions of the interaction of coronavirus with human antibodies. The emergence of new strains of coronavirus may potentially lead to the problem that existing antibodies will not have full neutralizing activity, which underlies such a phenomenon as antibody-dependent enhancement of infection. A decrease in antibody titers in recovered people may also lead to this phenomenon. In this regard, one of the necessary directions of research is the observation of cases of SARS-CoV-2 re-infection in order to find out the specificity of antibodies to newly emerging strains. Also, special attention should be paid to the cases and mechanisms of overcoming tissue barriers within the body by the coronavirus, including the blood-brain and placental barriers. These clinical studies should be accompanied by in vitro studies, which makes it urgent to develop relevant models of

\section{REFERENCES}

1. Gu J, Han B, Wang J. COVID-19: Gastrointestinal Manifestations and Potential Fecal-Oral Transmission. Gastroenterology (2020) 158:1518-9. doi: 10.1053/j.gastro.2020.02.054

2. Han J, Zhang X, He S, Jia P. Can the Coronavirus Disease be Transmitted From Food? A Review of Evidence, Risks, Policies and Knowledge Gaps. Environ Chem Lett (2020) 19:5-16. doi: 10.1007/s10311-020-01101-x

3. Xiao F, Tang M, Zheng X, Liu Y, Li X, Shan H. Evidence for Gastrointestinal Infection of SARS-CoV-2. Gastroenterology (2020) 158:1831-1833.e3. doi: 10.1053/j.gastro.2020.02.055

4. Mao R, Qiu Y, He J-S, Tan J-Y, Li X-H, Liang J, et al. Manifestations and Prognosis of Gastrointestinal and Liver Involvement in Patients With COVID-19: A Systematic Review and Meta-Analysis. Lancet Gastroenterol Hepatol (2020) 5:667-78. doi: 10.1016/S2468-1253(20)30126-6

5. Leung WK, To K-F, Chan PKS, Chan HLY, Wu AKL, Lee N, et al. Enteric Involvement of Severe Acute Respiratory Syndrome-Associated Coronavirus Infection. Gastroenterology (2003) 125:1011-7. doi: 10.1016/ s0016-5085(03)01215-0

6. Hoffmann M, Kleine-Weber H, Schroeder S, Krüger N, Herrler T, Erichsen S, et al. SARS-CoV-2 Cell Entry Depends on ACE2 and TMPRSS2 and Is Blocked by a Clinically Proven Protease Inhibitor. Cell (2020) 181:27180.e8. doi: 10.1016/j.cell.2020.02.052 various aspects of the coronavirus interaction with the human body. Experiments will help confirm or disprove the ability of coronavirus to overcome tissue barriers by transcytosis, including antibody-mediated transcytosis. The repurposing of previously approved drugs to target coronavirus endocytosis and transcytosis may be useful for fast COVID-19 treatment development without preclinical testing.

\section{AUTHOR CONTRIBUTIONS}

AT conceptualized and reviewed the work. SN worked on analysis of the bioinformatics data presented. EK worked on curation, analysis and visualization of the data presented, prepared the original draft, edited and reviewed it. All authors contributed to the article and approved the submitted version.

\section{FUNDING}

The reported study was funded by RFBR, project number 20-0460399 (AG, EK); Basic Research program at HSE University and funded by the Russian Academic Excellence Project '5-100' (SN).

7. Bertram S, Heurich A, Lavender H, Gierer S, Danisch S, Perin P, et al Influenza and SARS-Coronavirus Activating Proteases TMPRSS2 and HAT Are Expressed at Multiple Sites in Human Respiratory and Gastrointestinal Tracts. PloS One (2012) 7:e35876. doi: 10.1371/journal.pone.0035876

8. Lamers MM, Beumer J, van der Vaart J, Knoops K, Puschhof J, Breugem TI, et al. SARS-CoV-2 Productively Infects Human Gut Enterocytes. Science (2020) 369:50-4. doi: 10.1126/science.abc1669

9. Yao H, Song Y, Chen Y, Wu N, Xu J, Sun C, et al. Molecular Architecture of the SARS-CoV-2 Virus. Cell (2020) 183:730-8.e13. doi: 10.1016/ j.cell.2020.09.018

10. Ke Z, Oton J, Qu K, Cortese M, Zila V, McKeane L, et al. Structures and Distributions of SARS-CoV-2 Spike Proteins on Intact Virions. Nature (2020) 588:498-502. doi: 10.1038/s41586-020-2665-2

11. Chlanda P, Mekhedov E, Waters H, Schwartz CL, Fischer ER, Ryham RJ, et al. The Hemifusion Structure Induced by Influenza Virus Haemagglutinin Is Determined by Physical Properties of the Target Membranes. Nat Microbiol (2016) 1:16050. doi: 10.1038/nmicrobiol.2016.50

12. Turoňová B, Sikora M, Schürmann C, Hagen WJH, Welsch S, Blanc FEC, et al. In Situ Structural Analysis of SARS-CoV-2 Spike Reveals Flexibility Mediated by Three Hinges. Science (2020) 370:203-8. doi: 10.1126/science.abd5223

13. Yan R, Zhang Y, Li Y, Xia L, Guo Y, Zhou Q. Structural Basis for the Recognition of SARS-CoV-2 by Full-Length Human ACE2. Science (2020) 367:1444-8. doi: 10.1126/science.abb2762 
14. Ni D, Lau K, Lehmann F, Fränkl A, Hacker D, Pojer F, et al. Structural Investigation of ACE2 Dependent Disassembly of the Trimeric SARS-CoV-2 Spike Glycoprotein. bioRxiv (2020). doi: 10.1101/2020.10.12.336016

15. Clausen TM, Sandoval DR, Spliid CB, Pihl J, Perrett HR, Painter CD, et al. SARS-CoV-2 Infection Depends on Cellular Heparan Sulfate and ACE2. Cell (2020) 183:1043-57.e15. doi: 10.1016/j.cell.2020.09.033

16. Chi X, Yan R, Zhang JJ, Zhang G, Zhang Y, Hao M, et al. A Neutralizing Human Antibody Binds to the N-Terminal Domain of the Spike Protein of SARS-CoV-2. Science (2020) 369:650-5. doi: 10.1126/science.abc6952

17. Walls AC, Xiong X, Park Y-J, Tortorici MA, Snijder J, Quispe J, et al. Unexpected Receptor Functional Mimicry Elucidates Activation of Coronavirus Fusion. Cell (2019) 176:1026-39.e15. doi: 10.1016/j.cell.2018. 12.028

18. Barnes CO, West AP, Huey-Tubman KE, Hoffmann MAGG, Sharaf NG, Hoffman PR, et al. Structures of Human Antibodies Bound to SARS-CoV-2 Spike Reveal Common Epitopes and Recurrent Features of Antibodies. Cell (2020) 182:828-42.e16. doi: 10.1016/j.cell.2020.06.025

19. Lv Z, Deng Y-Q, Ye Q, Cao L, Sun C-Y, Fan C, et al. Structural Basis for Neutralization of SARS-CoV-2 and SARS-CoV by a Potent Therapeutic Antibody. Science (2020) 369:1505-9. doi: 10.1126/science.abc5881

20. Liu L, Wang P, Nair MS, Yu J, Rapp M, Wang Q, et al. Potent Neutralizing Antibodies Against Multiple Epitopes on SARS-CoV-2 Spike. Nature (2020) 584:450-6. doi: 10.1038/s41586-020-2571-7

21. Yan R, Wang R, Ju B, Yu J, Zhang Y, Liu N, et al. Structural Basis for Bivalent Binding and Inhibition of SARS-CoV-2 Infection by Human Potent Neutralizing Antibodies. Cell Res (2021) 31:517-25. doi: 10.1038/s41422021-00487-9

22. Tan YH, Liu M, Nolting B, Go JG, Gervay-Hague J, Liu GY. A Nanoengineering Approach for Investigation and Regulation of Protein Immobilization. ACS Nano (2008) 2:2374-84. doi: 10.1021/nn800508f

23. Bomsel M, Alfsen A. Entry of Viruses Through the Epithelial Barrier: Pathogenic Trickery. Nat Rev Mol Cell Biol (2003) 4:57-68. doi: 10.1038/ nrm1005

24. Helenius A. Virus Entry: Looking Back and Moving Forward. J Mol Biol (2018) 430:1853-62. doi: 10.1016/j.jmb.2018.03.034

25. Bagam P, Singh DP, Inda ME, Batra S. Unraveling the Role of Membrane Microdomains During Microbial Infections. Cell Biol Toxicol (2017) 33:42955. doi: 10.1007/s10565-017-9386-9

26. Fantini J, Di Scala C, Chahinian H, Yahi N. Structural and Molecular Modelling Studies Reveal a New Mechanism of Action of Chloroquine and Hydroxychloroquine Against SARS-CoV-2 Infection. Int J Antimicrob Agents (2020) 55:105960. doi: 10.1016/j.ijantimicag.2020.105960

27. Fantini J, Chahinian H, Yahi N. Synergistic Antiviral Effect of Hydroxychloroquine and Azithromycin in Combination Against SARSCoV-2: What Molecular Dynamics Studies of Virus-Host Interactions Reveal. Int J Antimicrob Agents (2020) 56:106020. doi: 10.1016/ j.ijantimicag.2020.106020

28. Earnest JT, Hantak MP, Li K, McCray PB, Perlman S, Gallagher T. The Tetraspanin CD9 Facilitates MERS-Coronavirus Entry by Scaffolding Host Cell Receptors and Proteases. PloS Pathog (2017) 13:e1006546. doi: 10.1371/ journal.ppat.1006546

29. Lu Y, Liu DX, Tam JP. Lipid Rafts Are Involved in SARS-CoV Entry Into Vero E6 Cells. Biochem Biophys Res Commun (2008) 369:344-9. doi: $10.1016 / j . b b r c .2008 .02 .023$

30. Glende J, Schwegmann-Wessels C, Al-Falah M, Pfefferle S, Qu X, Deng H, et al. Importance of Cholesterol-Rich Membrane Microdomains in the Interaction of the S Protein of SARS-Coronavirus With the Cellular Receptor Angiotensin-Converting Enzyme 2. Virology (2008) 381:215-21. doi: 10.1016/j.virol.2008.08.026

31. Khan AG, Pickl-Herk A, Gajdzik L, Marlovits TC, Fuchs R, Blaas D. Entry of a Heparan Sulphate-Binding HRV8 Variant Strictly Depends on Dynamin But Not on Clathrin, Caveolin, and Flotillin. Virology (2011) 412:55-67. doi: 10.1016/j.virol.2010.12.042

32. Meier O, Gastaldelli M, Boucke K, Hemmi S, Greber UF. Early Steps of Clathrin-Mediated Endocytosis Involved in Phagosomal Escape of Fcy Receptor-Targeted Adenovirus. J Virol (2005) 79:2604-13. doi: 10.1128/ JVI.79.4.2604-2613.2005
33. Letko M, Marzi A, Munster V. Functional Assessment of Cell Entry and Receptor Usage for SARS-CoV-2 and Other Lineage B Betacoronaviruses. Nat Microbiol (2020) 5:562-9. doi: 10.1038/s41564-020-0688-y

34. Matsuyama S, Ujike M, Morikawa S, Tashiro M, Taguchi F. ProteaseMediated Enhancement of Severe Acute Respiratory Syndrome Coronavirus Infection. Proc Natl Acad Sci (2005) 102:12543-7. doi: 10.1073/pnas.0503203102

35. Ou X, Liu Y, Lei X, Li P, Mi D, Ren L, et al. Characterization of Spike Glycoprotein of SARS-CoV-2 on Virus Entry and Its Immune CrossReactivity With SARS-CoV. Nat Commun (2020) 11:1620. doi: 10.1038/ s41467-020-15562-9

36. Heurich A, Hofmann-Winkler H, Gierer S, Liepold T, Jahn O, Pohlmann S. TMPRSS2 and ADAM17 Cleave ACE2 Differentially and Only Proteolysis by TMPRSS2 Augments Entry Driven by the Severe Acute Respiratory Syndrome Coronavirus Spike Protein. J Virol (2014) 88:1293-307. doi: $10.1128 /$ JVI.02202-13

37. Cantuti-Castelvetri L, Ojha R, Pedro LD, Djannatian M, Franz J, Kuivanen S, et al. Neuropilin-1 Facilitates SARS-CoV-2 Cell Entry and Infectivity. Science (2020) 370:856-60. doi: 10.1126/science.abd2985

38. Daly JL, Simonetti B, Klein K, Chen K-E, Williamson MK, Antón-Plágaro C, et al. Neuropilin-1 Is a Host Factor for SARS-CoV-2 Infection. Science (2020) 370:861-5. doi: 10.1126/science.abd3072

39. Wan Y, Shang J, Sun S, Tai W, Chen J, Geng Q, et al. Molecular Mechanism for Antibody-Dependent Enhancement of Coronavirus Entry. J Virol (2019) 94:e02015-19. doi: 10.1128/JVI.02015-19

40. Pyzik M, Sand KMK, Hubbard JJ, Andersen JT, Sandlie I, Blumberg RS. The Neonatal Fc Receptor (FcRn): A Misnomer? Front Immunol (2019) 10:1540. doi: $10.3389 /$ fimmu.2019.01540

41. Sheridan C. Convalescent Serum Lines Up as First-Choice Treatment for Coronavirus. Nat Biotechnol (2020) 38:655-8. doi: 10.1038/d41587-02000011-1

42. Vabret N, Britton GJ, Gruber C, Hegde S, Kim J, Kuksin M, et al. Immunology of COVID-19: Current State of the Science. Immunity (2020) 52:910-41. doi: 10.1016/j.immuni.2020.05.002

43. Koyama T, Weeraratne D, Snowdon JL, Parida L. Emergence of Drift Variants That May Affect COVID-19 Vaccine Development and Antibody Treatment. Pathogens (2020) 9:324. doi: 10.3390/pathogens9050324

44. Zheng M, Song L. Novel Antibody Epitopes Dominate the Antigenicity of Spike Glycoprotein in SARS-CoV-2 Compared to SARS-CoV. Cell Mol Immunol (2020) 17:536-8. doi: 10.1038/s41423-020-0385-Z

45. Jiang S, Hillyer C, Du L. Neutralizing Antibodies Against SARS-CoV-2 and Other Human Coronaviruses. Trends Immunol (2020) 41:355-9. doi: 10.1016/j.it.2020.03.007

46. Moustafa AM, Planet P. Rapid Whole Genome Sequence Typing Reveals Multiple Waves of SARS-CoV-2 Spread. bioRxiv (2020). doi: 10.1101/ 2020.06.08.139055

47. Chen K, Magri G, Grasset EK, Cerutti A. Rethinking Mucosal Antibody Responses: IgM, IgG and IgD Join IgA. Nat Rev Immunol (2020) 20:427-41. doi: 10.1038/s41577-019-0261-1

48. Breitfeld PP, Harris JM, Mostov KE. Postendocytotic Sorting of the Ligand for the Polymeric Immunoglobulin Receptor in Madin-Darby Canine Kidney Cells. J Cell Biol (1989) 109:475-86. doi: 10.1083/jcb.109.2.475

49. Kanaya T, Williams IR, Ohno H. Intestinal M Cells: Tireless Samplers of Enteric Microbiota. Traffic (2020) 21:34-44. doi: 10.1111/tra.12707

50. Hamdan TA, Lang PA, Lang KS. The Diverse Functions of the Ubiquitous Fc $\gamma$ Receptors and Their Unique Constituent, Fcr $\gamma$ Subunit. Pathogens (2020) 9:140. doi: 10.3390/pathogens9020140

51. Stapleton NM, Andersen JT, Stemerding AM, Bjarnarson SP, Verheul RC, Gerritsen J, et al. Competition for FcRn-Mediated Transport Gives Rise to Short Half-Life of Human IgG3 and Offers Therapeutic Potential. Nat Commun (2011) 2:599. doi: 10.1038/ncomms1608

52. Damelang T, Rogerson SJ, Kent SJ, Chung AW. Role of IgG3 in Infectious Diseases. Trends Immunol (2019) 40:197-211. doi: 10.1016/j.it.2019.01.005

53. Nersisyan S, Shkurnikov M, Turchinovich A, Knyazev E, Tonevitsky A. Integrative Analysis of miRNA and mRNA Sequencing Data Reveals Potential Regulatory Mechanisms of ACE2 and TMPRSS2. PloS One (2020) 15:e0235987. doi: 10.1371/journal.pone.0235987 
54. Zhang C, Shi L, Wang F-S. Liver Injury in COVID-19: Management and Challenges. Lancet Gastroenterol Hepatol (2020) 5:428-30. doi: 10.1016/ S2468-1253(20)30057-1

55. Gorshkov K, Susumu K, Chen J, Xu M, Pradhan M, Zhu W, et al. Quantum Dot-Conjugated SARS-CoV-2 Spike Pseudo-Virions Enable Tracking of Angiotensin Converting Enzyme 2 Binding and Endocytosis. ACS Nano (2020) 14:12234-47. doi: 10.1021/acsnano.0c05975

56. Bayati A, Kumar R, Francis V, McPherson PS. SARS-CoV-2 Infects Cells After Viral Entry via Clathrin-Mediated Endocytosis. J Biol Chem (2021) 296:100306. doi: 10.1016/j.jbc.2021.100306

57. Mészáros B, Sámano-Sánchez H, Alvarado-Valverde J, Čalyševa J, MartínezPérez E, Alves R, et al. Short Linear Motif Candidates in the Cell Entry System Used by SARS-CoV-2 and Their Potential Therapeutic Implications. Sci Signal (2021) 14:eabd0334. doi: 10.1126/scisignal.abd0334

58. Kliche J, Kuss H, Ali M, Ivarsson Y. Cytoplasmic Short Linear Motifs in ACE2 and Integrin $\beta 3$ Link SARS-CoV-2 Host Cell Receptors to Mediators of Endocytosis and Autophagy. Sci Signal (2021) 14:eabf1117. doi: 10.1126/ scisignal.abf1117

59. Sora V, Kumar M, Maiani E, Lambrughi M, Tiberti M, Papaleo E. Structure and Dynamics in the ATG8 Family From Experimental to Computational Techniques. Front Cell Dev Biol (2020) 8:420. doi: 10.3389/fcell.2020.00420

60. Inoue $\mathrm{Y}$, Tanaka N, Tanaka Y, Inoue S, Morita K, Zhuang M, et al. ClathrinDependent Entry of Severe Acute Respiratory Syndrome Coronavirus Into Target Cells Expressing ACE2 With the Cytoplasmic Tail Deleted. J Virol (2007) 81:8722-9. doi: 10.1128/JVI.00253-07

61. Wang H, Yang P, Liu K, Guo F, Zhang Y, Zhang G, et al. SARS Coronavirus Entry Into Host Cells Through a Novel Clathrin- and Caveolae-Independent Endocytic Pathway. Cell Res (2008) 18:290-301. doi: 10.1038/cr.2008.15

62. Pang H-B, Braun GB, Friman T, Aza-Blanc P, Ruidiaz ME, Sugahara KN, et al. An Endocytosis Pathway Initiated Through Neuropilin-1 and Regulated by Nutrient Availability. Nat Commun (2014) 5:4904. doi: 10.1038/ncomms5904

63. Lanahan A, Zhang X, Fantin A, Zhuang Z, Rivera-Molina F, Speichinger K, et al. The Neuropilin 1 Cytoplasmic Domain Is Required for VEGF-ADependent Arteriogenesis. Dev Cell (2013) 25:156-68. doi: 10.1016/ j.devcel.2013.03.019

64. Takano T, Kawakami C, Yamada S, Satoh R, Hohdatsu T. AntibodyDependent Enhancement Occurs Upon Re-Infection With the Identical Serotype Virus in Feline Infectious Peritonitis Virus Infection. J Vet Med Sci (2008) 70:1315-21. doi: 10.1292/jvms.70.1315

65. Jaume M, Yip MS, Kam YW, Cheung CY, Kien F, Roberts A, et al. SARS CoV Subunit Vaccine: Antibody-Mediated Neutralisation and Enhancement. Hong Kong Med J = Xianggang yi xue za zhi (2012) 18 (Suppl 2):31-6.

66. Yip M, Leung NH, Cheung C, Li P, Lee HH, Daëron M, et al. AntibodyDependent Infection of Human Macrophages by Severe Acute Respiratory Syndrome Coronavirus. Virol J (2014) 11:82. doi: 10.1186/1743-422X-11-82

67. Wang S-F, Tseng S-P, Yen C-H, Yang J-Y, Tsao C-H, Shen C-W, et al. Antibody-Dependent SARS Coronavirus Infection Is Mediated by Antibodies Against Spike Proteins. Biochem Biophys Res Commun (2014) 451:208-14. doi: 10.1016/j.bbrc.2014.07.090

68. Wang Q, Zhang L, Kuwahara K, Li L, Liu Z, Li T, et al. Immunodominant SARS Coronavirus Epitopes in Humans Elicited Both Enhancing and Neutralizing Effects on Infection in Non-Human Primates. ACS Infect Dis (2016) 2:361-76. doi: 10.1021/acsinfecdis.6b00006

69. Liu L, Wei Q, Lin Q, Fang J, Wang H, Kwok H, et al. Anti-Spike IgG Causes Severe Acute Lung Injury by Skewing Macrophage Responses During Acute SARS-CoV Infection. JCI Insight (2019) 4:e123158. doi: 10.1172/ jci.insight. 123158

70. Tetro JA. Is COVID-19 Receiving ADE From Other Coronaviruses? Microbes Infect (2020) 22:72-3. doi: 10.1016/j.micinf.2020.02.006

71. Cao X. COVID-19: Immunopathology and Its Implications for Therapy. Nat Rev Immunol (2020) 20:269-70. doi: 10.1038/s41577-020-0308-3

72. Iwasaki A, Yang Y. The Potential Danger of Suboptimal Antibody Responses in COVID-19. Nat Rev Immunol (2020) 20:339-41. doi: 10.1038/s41577020-0321-6

73. Huang AT, Garcia-Carreras B, Hitchings MDT, Yang B, Katzelnick LC, Rattigan SM, et al. A Systematic Review of Antibody Mediated Immunity to
Coronaviruses: Kinetics, Correlates of Protection, and Association With Severity. Nat Commun (2020) 11:4704. doi: 10.1038/s41467-020-18450-4

74. Tuma PL, Hubbard AL. Transcytosis: Crossing Cellular Barriers. Physiol Rev (2003) 83:871-932. doi: 10.1152/physrev.00001.2003

75. Jones JH, Minshall RD. Lung Endothelial Transcytosis. Compr Physiol (2020) 10:491-508. doi: 10.1002/cphy.c190012

76. Salimi H, Cain MD, Jiang X, Roth RA, Beatty WL, Sun C, et al. Encephalitic Alphaviruses Exploit Caveola-Mediated Transcytosis at the Blood-Brain Barrier for Central Nervous System Entry. MBio (2020) 11:e02731-19. doi: $10.1128 / \mathrm{mBio} .02731-19$

77. Hocini H, Bomsel M. Infectious Human Immunodeficiency Virus Can Rapidly Penetrate a Tight Human Epithelial Barrier by Transcytosis in a Process Impaired by Mucosal Immunoglobulins. J Infect Dis (1999) 179: S448-53. doi: $10.1086 / 314802$

78. Tugizov SM, Herrera R, Palefsky JM. Epstein-Barr Virus Transcytosis Through Polarized Oral Epithelial Cells. J Virol (2013) 87:8179-94. doi: 10.1128/JVI.00443-13

79. Kerneis S. Conversion by Peyer's Patch Lymphocytes of Human Enterocytes Into M Cells That Transport Bacteria. Science (1997) 277:949-52. doi: $10.1126 /$ science.277.5328.949

80. Shang J, Wan Y, Luo C, Ye G, Geng Q, Auerbach A, et al. Cell Entry Mechanisms of SARS-CoV-2. Proc Natl Acad Sci (2020) 117:11727-34. doi: 10.1073/pnas.2003138117

81. Boulware DR, Pullen MF, Bangdiwala AS, Pastick KA, Lofgren SM, Okafor EC, et al. A Randomized Trial of Hydroxychloroquine as Postexposure Prophylaxis for Covid-19. N Engl J Med (2020) 383:517-25. doi: 10.1056/ NEJMoa2016638

82. RECOVERY Collaborative Group, Horby P, Mafham M, Linsell L, Bell JL, Staplin N, et al. Effect of Hydroxychloroquine in Hospitalized Patients With Covid-19. N Engl J Med (2020)383:2030-40. doi: 10.1056/NEJMoa2022926

83. Sahraei Z, Shabani M, Shokouhi S, Saffaei A. Aminoquinolines Against Coronavirus Disease 2019 (COVID-19): Chloroquine or Hydroxychloroquine. Int J Antimicrob Agents (2020) 55:105945. doi: 10.1016/j.ijantimicag.2020.105945

84. Meckes DG, Raab-Traub N. Microvesicles and Viral Infection. J Virol (2011) 85:12844-54. doi: 10.1128/JVI.05853-11

85. Münz C. The Autophagic Machinery in Viral Exocytosis. Front Microbiol (2017) 8:269. doi: 10.3389/fmicb.2017.00269

86. Pallet N, Sirois I, Bell C, Hanafi L-A, Hamelin K, Dieudé M, et al. A Comprehensive Characterization of Membrane Vesicles Released by Autophagic Human Endothelial Cells. Proteomics (2013) 13:1108-20. doi: 10.1002/pmic.201200531

87. Jackson WT, Giddings TH, Taylor MP, Mulinyawe S, Rabinovitch M, Kopito RR, et al. Subversion of Cellular Autophagosomal Machinery by RNA Viruses. PloS Biol (2005) 3:e156. doi: 10.1371/journal.pbio.0030156

88. Robinson SM, Tsueng G, Sin J, Mangale V, Rahawi S, McIntyre LL, et al. Coxsackievirus B Exits the Host Cell in Shed Microvesicles Displaying Autophagosomal Markers. PloS Pathog (2014) 10:e1004045. doi: 10.1371/ journal.ppat. 1004045

89. Chen Y-H, Du W, Hagemeijer MC, Takvorian PM, Pau C, Cali A, et al. Phosphatidylserine Vesicles Enable Efficient En Bloc Transmission of Enteroviruses. Cell (2015) 160:619-30. doi: 10.1016/j.cell.2015.01.032

90. Nowag H, Guhl B, Thriene K, Romao S, Ziegler U, Dengjel J, et al. Macroautophagy Proteins Assist Epstein Barr Virus Production and Get Incorporated Into the Virus Particles. EBioMedicine (2014) 1:116-25. doi: 10.1016/j.ebiom.2014.11.007

91. Granato M, Santarelli R, Farina A, Gonnella R, Lotti LV, Faggioni A, et al. Epstein-Barr Virus Blocks the Autophagic Flux and Appropriates the Autophagic Machinery To Enhance Viral Replication. J Virol (2014) 88:12715-26. doi: 10.1128/JVI.02199-14

92. Buckingham EM, Jarosinski KW, Jackson W, Carpenter JE, Grose C. Exocytosis of Varicella-Zoster Virus Virions Involves a Convergence of Endosomal and Autophagy Pathways. J Virol (2016) 90:8673-85. doi: 10.1128/JVI.00915-16

93. Ding B, Zhang G, Yang X, Zhang S, Chen L, Yan Q, et al. Phosphoprotein of Human Parainfluenza Virus Type 3 Blocks Autophagosome-Lysosome Fusion to Increase Virus Production. Cell Host Microbe (2014) 15:564-77. doi: 10.1016/j.chom.2014.04.004 
94. Beale R, Wise H, Stuart A, Ravenhill BJ, Digard P, Randow F. A LC3Interacting Motif in the Influenza A Virus M2 Protein Is Required to Subvert Autophagy and Maintain Virion Stability. Cell Host Microbe (2014) 15:23947. doi: 10.1016/j.chom.2014.01.006

95. Gannagé M, Dormann D, Albrecht R, Dengjel J, Torossi T, Rämer PC, et al. Matrix Protein 2 of Influenza A Virus Blocks Autophagosome Fusion With Lysosomes. Cell Host Microbe (2009) 6:367-80. doi: 10.1016/j.chom. 2009.09.005

96. Metz P, Chiramel A, Chatel-Chaix L, Alvisi G, Bankhead P, Mora-Rodríguez $\mathrm{R}$, et al. Dengue Virus Inhibition of Autophagic Flux and Dependency of Viral Replication on Proteasomal Degradation of the Autophagy Receptor P62. J Virol (2015) 89:8026-41. doi: 10.1128/JVI.00787-15

97. Shrivastava S, Devhare P, Sujijantarat N, Steele R, Kwon Y-C, Ray R, et al. Knockdown of Autophagy Inhibits Infectious Hepatitis C Virus Release by the Exosomal Pathway. J Virol (2016) 90:1387-96. doi: 10.1128/JVI.02383-15

98. Wang L, Tian Y, Ou JJ. HCV Induces the Expression of Rubicon and UVRAG to Temporally Regulate the Maturation of Autophagosomes and Viral Replication. PloS Pathog (2015) 11:e1004764. doi: 10.1371/ journal.ppat.1004764

99. Mohl B-P, Bartlett C, Mankouri J, Harris M. Early Events in the Generation of Autophagosomes Are Required for the Formation of Membrane Structures Involved in Hepatitis C Virus Genome Replication. J Gen Virol (2016) 97:680-93. doi: 10.1099/jgv.0.000387

100. Prentice E, Jerome WG, Yoshimori T, Mizushima N, Denison MR. Coronavirus Replication Complex Formation Utilizes Components of Cellular Autophagy. J Biol Chem (2004) 279:10136-41. doi: 10.1074/jbc.M306124200

101. Prentice E, McAuliffe J, Lu X, Subbarao K, Denison MR. Identification and Characterization of Severe Acute Respiratory Syndrome Coronavirus Replicase Proteins. J Virol (2004) 78:9977-86. doi: 10.1128/JVI.78.18.9977-9986.2004

102. Chen X, Wang K, Xing Y, Tu J, Yang X, Zhao Q, et al. Coronavirus Membrane-Associated Papain-Like Proteases Induce Autophagy Through Interacting With Beclin1 to Negatively Regulate Antiviral Innate Immunity. Protein Cell (2014) 5:912-27. doi: 10.1007/s13238-014-0104-6

103. Gassen NC, Niemeyer D, Muth D, Corman VM, Martinelli S, Gassen A, et al. SKP2 Attenuates Autophagy Through Beclin1-Ubiquitination and Its Inhibition Reduces MERS-Coronavirus Infection. Nat Commun (2019) 10:5770. doi: 10.1038/s41467-019-13659-4

104. Gassen NC, Papies J, Bajaj T, Emanuel J, Dethloff F, Chua RL, et al. SARSCoV-2-Mediated Dysregulation of Metabolism and Autophagy Uncovers Host-Targeting Antivirals. Nat Commun (2021) 12:3818. doi: 10.1038/ s41467-021-24007-w

105. Ramakrishnaiah V, Thumann C, Fofana I, Habersetzer F, Pan Q, de Ruiter PE, et al. Exosome-Mediated Transmission of Hepatitis C Virus Between Human Hepatoma Huh7.5 Cells. Proc Natl Acad Sci (2013) 110:13109-13. doi: $10.1073 /$ pnas. 1221899110

106. Hirai-Yuki A, Hensley L, Whitmire JK, Lemon SM. Biliary Secretion of Quasi-Enveloped Human Hepatitis A Virus. MBio (2016) 7:e01998-16. doi: $10.1128 / \mathrm{mBio} .01998-16$

107. Kadiu I, Narayanasamy P, Dash PK, Zhang W, Gendelman HE. Biochemical and Biologic Characterization of Exosomes and Microvesicles as Facilitators of HIV-1 Infection in Macrophages. J Immunol (2012) 189:744-54. doi: 10.4049/jimmunol.1102244

108. Izquierdo-Useros N, Naranjo-Gómez M, Archer J, Hatch SC, Erkizia I, Blanco J, et al. Capture and Transfer of HIV-1 Particles by Mature Dendritic Cells Converges With the Exosome-Dissemination Pathway. Blood (2009) 113:2732-41. doi: 10.1182/blood-2008-05-158642

109. Wiley RD, Gummuluru S. Immature Dendritic Cell-Derived Exosomes can Mediate HIV-1 Trans Infection. Proc Natl Acad Sci USA (2006) 103:738-43. doi: 10.1073/pnas.0507995103

110. Raab-Traub N, Dittmer DP. Viral Effects on the Content and Function of Extracellular Vesicles. Nat Rev Microbiol (2017) 15:559-72. doi: 10.1038/ nrmicro.2017.60

111. Gupta S, Gach JS, Becerra JC, Phan TB, Pudney J, Moldoveanu Z, et al. The Neonatal Fc Receptor (FcRn) Enhances Human Immunodeficiency Virus Type 1 (HIV-1) Transcytosis Across Epithelial Cells. PloS Pathog (2013) 9: e1003776. doi: 10.1371/journal.ppat.1003776

112. Maidji E, McDonagh S, Genbacev O, Tabata T, Pereira L. Maternal Antibodies Enhance or Prevent Cytomegalovirus Infection in the Placenta by Neonatal Fc Receptor-Mediated Transcytosis. Am J Pathol (2006) 168:1210-26. doi: 10.2353/ajpath.2006.050482

113. Yoshida M, Claypool SM, Wagner JS, Mizoguchi E, Mizoguchi A, Roopenian DC, et al. Human Neonatal Fc Receptor Mediates Transport of IgG Into Luminal Secretions for Delivery of Antigens to Mucosal Dendritic Cells. Immunity (2004) 20:769-83. doi: 10.1016/j.immuni.2004.05.007

114. Takeda A, Sweet RW, Ennis FA. Two Receptors Are Required for AntibodyDependent Enhancement of Human Immunodeficiency Virus Type 1 Infection: CD4 and Fc Gamma R. J Virol (1990) 64:5605-10. doi: 10.1128/ JVI.64.11.5605-5610.1990

115. Rhea EM, Logsdon AF, Hansen KM, Williams LM, Reed MJ, Baumann KK, et al. The S1 Protein of SARS-CoV-2 Crosses the Blood-Brain Barrier in Mice. Nat Neurosci (2021) 24:368-78. doi: 10.1038/s41593-020-00771-8

116. Zhou L, Zhang M, Wang J, Gao J. Sars-Cov-2: Underestimated Damage to Nervous System. Travel Med Infect Dis (2020) 36:101642. doi: 10.1016/ j.tmaid.2020.101642

117. Hosier H, Farhadian SF, Morotti RA, Deshmukh U, Lu-Culligan A, Campbell $\mathrm{KH}$, et al. SARS-CoV-2 Infection of the Placenta. J Clin Invest (2020) 130:4947-53. doi: 10.1172/JCI139569

118. Algarroba GN, Rekawek P, Vahanian SA, Khullar P, Palaia T, Peltier MR, et al. Visualization of Severe Acute Respiratory Syndrome Coronavirus 2 Invading the Human Placenta Using Electron Microscopy. Am J Obstet Gynecol (2020) 223:275-8. doi: 10.1016/j.ajog.2020.05.023

119. Zeng $\mathrm{H}, \mathrm{Xu} \mathrm{C}$, Fan J, Tang $\mathrm{Y}$, Deng Q, Zhang W, et al. Antibodies in Infants Born to Mothers With COVID-19 Pneumonia. JAMA (2020) 323:1848-9. doi: 10.1001/jama.2020.4861

120. Dong L, Tian J, He S, Zhu C, Wang J, Liu C, et al. Possible Vertical Transmission of SARS-CoV-2 From an Infected Mother to Her Newborn. JAMA (2020) 323:1846-8. doi: 10.1001/jama.2020.4621

121. Egloff C, Vauloup-Fellous C, Picone O, Mandelbrot L, Roques P. Evidence and Possible Mechanisms of Rare Maternal-Fetal Transmission of SARSCoV-2. J Clin Virol (2020) 128:104447. doi: 10.1016/j.jcv.2020.104447

122. Mestecky J. Protective Activities of Mucosal Antibodies. In: H Kiyono and DW Pascual, editors. Mucosal Vaccines. Amsterdam: Elsevier/Academic Press (2020). p. 71-84. doi: 10.1016/B978-0-12-811924-2.00004-3

123. Dash S, Balasubramaniam M, Villalta F, Dash C, Pandhare J. Impact of Cocaine Abuse on HIV Pathogenesis. Front Microbiol (2015) 6:1111. doi: $10.3389 /$ fmicb.2015.01111

124. Dong D, Xie W, Liu M. Alteration of Cell Junctions During Viral Infection. Thorac Cancer (2020) 11:519-25. doi: 10.1111/1759-7714.13344

125. Torres-Flores JM, Silva-Ayala D, Espinoza MA, López S, Arias CF. The Tight Junction Protein JAM-A Functions as Coreceptor for Rotavirus Entry Into MA104 Cells. Virology (2015) 475:172-8. doi: 10.1016/j.virol.2014.11.016

126. Zhu Y-Z. How Hepatitis C Virus Invades Hepatocytes: The Mystery of Viral Entry. World J Gastroenterol (2014) 20:3457. doi: 10.3748/wjg.v20.i13.3457

127. Heuser S, Hufbauer M, Marx B, Tok A, Majewski S, Pfister H, et al. The Levels of Epithelial Anchor Proteins $\beta$-Catenin and Zona Occludens-1 Are Altered by E7 of Human Papillomaviruses 5 and 8. J Gen Virol (2016) 97:463-72. doi: 10.1099/jgv.0.000363

128. Realpe M, Espinosa R, López S, Arias CF. Rotaviruses Require Basolateral Molecules for Efficient Infection of Polarized MDCKII Cells. Virus Res (2010) 147:231-41. doi: 10.1016/j.virusres.2009.11.005

129. Excoffon KJDA, Guglielmi KM, Wetzel JD, Gansemer ND, Campbell JA, Dermody TS, et al. Reovirus Preferentially Infects the Basolateral Surface and Is Released From the Apical Surface of Polarized Human Respiratory Epithelial Cells. J Infect Dis (2008) 197:1189-97. doi: 10.1086/529515

130. Roe K, Kumar M, Lum S, Orillo B, Nerurkar VR, Verma S. West Nile VirusInduced Disruption of the Blood-Brain Barrier in Mice Is Characterized by the Degradation of the Junctional Complex Proteins and Increase in Multiple Matrix Metalloproteinases. J Gen Virol (2012) 93:1193-203. doi: 10.1099/vir.0.040899-0

131. Kanlaya R, Pattanakitsakul S, Sinchaikul S, Chen S-T, Thongboonkerd V. Alterations in Actin Cytoskeletal Assembly and Junctional Protein Complexes in Human Endothelial Cells Induced by Dengue Virus Infection and Mimicry of Leukocyte Transendothelial Migration. J Proteome Res (2009) 8:2551-62. doi: 10.1021/pr900060g

132. Christensen NR, Čalyševa J, Fernandes EFA, Lüchow S, Clemmensen LS, Haugaard-Kedström LM, et al. PDZ Domains as Drug Targets. Adv Ther (2019) 2:1800143. doi: 10.1002/adtp.201800143 
133. Gutiérrez-González LH, Santos-Mendoza T. Viral Targeting of PDZ Polarity Proteins in the Immune System as a Potential Evasion Mechanism. FASEB J (2019) 33:10607-17. doi: 10.1096/fj.201900518R

134. James C, Roberts S. Viral Interactions With PDZ Domain-Containing Proteins-An Oncogenic Trait? Pathogens (2016) 5:8. doi: 10.3390/ pathogens5010008

135. Chai J, Cai Y, Pang C, Wang L, McSweeney S, Shanklin J, et al. Structural Basis for SARS-CoV-2 Envelope Protein Recognition of Human Cell Junction Protein PALS1. Nat Commun (2021) 12:3433. doi: 10.1038/s41467-021-23533-x

136. Teoh K-T, Siu Y-L, Chan W-L, Schlüter MA, Liu C-J, Peiris JSM, et al. The SARS Coronavirus E Protein Interacts With PALS1 and Alters Tight Junction Formation and Epithelial Morphogenesis. Mol Biol Cell (2010) 21:3838-52. doi: 10.1091/mbc.e10-04-0338

137. Shepley-McTaggart A, Sagum CA, Oliva I, Rybakovsky E, DiGuilio K, Liang J, et al. SARS-CoV-2 Envelope (E) Protein Interacts With PDZ-Domain-2 of Host Tight Junction Protein ZO1. PloS One (2021) 16:e0251955. doi: 10.1371/journal.pone.0251955

138. Jimenez-Guardeño JM, Nieto-Torres JL, DeDiego ML, Regla-Nava JA, Fernandez-Delgado R, Castaño-Rodriguez C, et al. The PDZ-Binding Motif of Severe Acute Respiratory Syndrome Coronavirus Envelope Protein Is a Determinant of Viral Pathogenesis. PloS Pathog (2014) 10: e1004320. doi: 10.1371/journal.ppat.1004320

139. Caillet-Saguy C, Durbesson F, Rezelj VV, Gogl G, Tran QD, Twizere J-C, et al. Host PDZ-Containing Proteins Targeted by SARS-CoV-2. FEBS $J$ (2021), febs.15881. doi: 10.1111/febs.15881

140. Buzhdygan TP, DeOre BJ, Baldwin-Leclair A, Bullock TA, McGary HM, Khan JA, et al. The SARS-CoV-2 Spike Protein Alters Barrier Function in 2D Static and 3D Microfluidic In-Vitro Models of the Human Blood-Brain Barrier. Neurobiol Dis (2020) 146:105131. doi: 10.1016/j.nbd.2020.105131

141. Hao S, Ning K, Kuz CA, Vorhies K, Yan Z, Qiu J. Long-Term Modeling of SARS-CoV-2 Infection of In Vitro Cultured Polarized Human Airway Epithelium. MBio (2020) 11:e02852-20. doi: 10.1128/mBio.02852-20

142. Busquet F, Hartung T, Pallocca G, Rovida C, Leist M. Harnessing the Power of Novel Animal-Free Test Methods for the Development of COVID-19 Drugs and Vaccines. Arch Toxicol (2020) 94:2263-72. doi: 10.1007/s00204-020-02787-2

143. Marx U, Akabane T, Andersson TB, Baker E, Beilmann M, Beken S, et al. Biology-Inspired Microphysiological Systems to Advance Patient Benefit and Animal Welfare in Drug Development. ALTEX (2020) 37:365-94. doi: 10.14573/altex.2001241

144. Samatov TR, Shkurnikov MU, Tonevitskaya SA, Tonevitsky AG. Modelling the Metastatic Cascade by In Vitro Microfluidic Platforms. Prog Histochem Cytochem (2015) 49:21-9. doi: 10.1016/j.proghi.2015.01.001

145. Grivel J-C, Margolis L. Use of Human Tissue Explants to Study Human Infectious Agents. Nat Protoc (2009) 4:256-69. doi: 10.1038/nprot.2008.245

146. Nikulin SV, Knyazev EN, Poloznikov AA, Shilin SA, Gazizov IN, Zakharova GS, et al. Expression of SLC30A10 and SLC23A3 Transporter mRNAs in Caco-2 Cells Correlates With an Increase in the Area of the Apical Membrane. Mol Biol (2018) 52:577-82. doi: 10.1134/S0026893318040131

147. Nikulin SV, Knyazev EN, Gerasimenko TN, Shilin SA, Gazizov IN, Zakharova GS, et al. Non-Invasive Evaluation of Extracellular Matrix Formation in the Intestinal Epithelium. Bull Exp Biol Med (2018) 166:358. doi: 10.1007/s10517-018-4283-7

148. Nikulin SV, Knyazev EN, Maltseva DV, Sakharov DA, Gerasimenko TN. Use of Impedance Spectroscopy to Assess the Effect of Laminins on the In Vitro Differentiation of Intestinal Cells. Biotekhnologiya (2019) 35:102-7. doi: 10.21519/0234-2758-2019-35-6-102-107

149. Sakharov D, Maltseva D, Knyazev E, Nikulin S, Poloznikov A, Shilin S, et al. Towards Embedding Caco-2 Model of Gut Interface in a Microfluidic Device to Enable Multi-Organ Models for Systems Biology. BMC Syst Biol (2019) 13:19. doi: 10.1186/s12918-019-0686-y

150. Samatov TR, Galatenko VV, Senyavina NV, Galatenko AV, Shkurnikov MY, Tonevitskaya SA, et al. miRNA-Mediated Expression Switch of Cell Adhesion Genes Driven by Microcirculation in Chip. BioChip J (2017) 11:262-9. doi: 10.1007/s13206-017-1305-x

151. Samatov TR, Senyavina NV, Galatenko VV, Trushkin EV, Tonevitskaya SA, Alexandrov DE, et al. Tumour-Like Druggable Gene Expression Pattern of CaCo2 Cells in Microfluidic Chip. BioChip J (2016) 10:215-20. doi: 10.1007/ s13206-016-0308-3
152. Si L, Bai H, Rodas M, Cao W, Oh CY, Jiang A, et al. Human-Airway-on-aChip for the Rapid Identification of Candidate Antiviral Therapeutics and Prophylactics. Nat Biomed Eng (2021) 5:815-29. doi: 10.1038/s41551-02100718-9

153. Mossel EC, Huang C, Narayanan K, Makino S, Tesh RB, Peters CJ. Exogenous ACE2 Expression Allows Refractory Cell Lines To Support Severe Acute Respiratory Syndrome Coronavirus Replication. J Virol (2005) 79:3846-50. doi: 10.1128/JVI.79.6.3846-3850.2005

154. Chan PKS, To K-F, Lo AWI, Cheung JLK, Chu I, Au FWL, et al. Persistent Infection of SARS Coronavirus in Colonic Cells In Vitro. J Med Virol (2004) 74:1-7. doi: 10.1002/jmv.20138

155. Cinatl J, Hoever G, Morgenstern B, Preiser W, Vogel J-U, Hofmann W-K, et al. Infection of Cultured Intestinal Epithelial Cells With Severe Acute Respiratory Syndrome Coronavirus. Cell Mol Life Sci C (2004) 61:2100-12. doi: 10.1007/s00018-004-4222-9

156. Ölander M, Wiśniewski JR, Matsson P, Lundquist P, Artursson P. The Proteome of Filter-Grown Caco-2 Cells With a Focus on Proteins Involved in Drug Disposition. J Pharm Sci (2016) 105:817-27. doi: 10.1016/ j.xphs.2015.10.030

157. Guo J, Li F, Qian S, Bi D, He Q, Jin H, et al. TGEV Infection Up-Regulates FcRn Expression via Activation of NF-kb Signaling. Sci Rep (2016) 6:32154. doi: $10.1038 /$ srep32154

158. Qian S, Gao Z, Cao R, Yang K, Cui Y, Li S, et al. Transmissible Gastroenteritis Virus Infection Up-Regulates FcRn Expression via Nucleocapsid Protein and Secretion of TGF- $\beta$ in Porcine Intestinal Epithelial Cells. Front Microbiol (2020) 10:3085. doi: 10.3389/fmicb.2019.03085

159. Qian S, Jia X, Gao Z, Zhang W, Xu Q, Li Z. Isolation and Identification of Porcine Deltacoronavirus and Alteration of Immunoglobulin Transport Receptors in the Intestinal Mucosa of PDCoV-Infected Piglets. Viruses (2020) 12:79. doi: 10.3390/v12010079

160. Song X, Li R, Deng H, Li Y, Cui Y, Zhang H, et al. Receptor Mediated Transcytosis in Biological Barrier: The Influence of Receptor Character and Their Ligand Density on the Transmembrane Pathway of Active-Targeting Nanocarriers. Biomaterials (2018) 180:78-90. doi: 10.1016/j.biomaterials. 2018.07.006

161. Rottier PJ, Horzinek MC, Strous GJ, Rossen JW. Mouse Hepatitis Virus Strain A59 Is Released From Opposite Sides of Different Epithelial Cell Types. J Gen Virol (1997) 78:61-9. doi: 10.1099/0022-1317-78-1-61

162. Ober RJ, Martinez C, Lai X, Zhou J, Ward ES. Exocytosis of IgG as Mediated by the Receptor, FcRn: An Analysis at the Single-Molecule Level. Proc Natl Acad Sci (2004) 101:11076-81. doi: 10.1073/pnas.0402970101

163. Ward ES, Martinez C, Vaccaro C, Zhou J, Tang Q, Ober RJ. From Sorting Endosomes to Exocytosis: Association of Rab4 and Rab11 GTPases With the Fc Receptor, FcRn, During Recycling. Mol Biol Cell (2005) 16:2028-38. doi: 10.1091/mbc.e04-08-0735

164. Weflen AW, Baier N, Tang Q-J, Van den Hof M, Blumberg RS, Lencer WI, et al. Multivalent Immune Complexes Divert FcRn to Lysosomes by Exclusion From Recycling Sorting Tubules. Mol Biol Cell (2013) 24:2398405. doi: 10.1091/mbc.e13-04-0174

165. Maxfield FR, McGraw TE. Endocytic Recycling. Nat Rev Mol Cell Biol (2004) 5:121-32. doi: 10.1038/nrm1315

166. Berthiaume EP, Medina C, Swanson JA. Molecular Size-Fractionation During Endocytosis in Macrophages. J Cell Biol (1995) 129:989-98. doi: $10.1083 /$ jcb.129.4.989

167. Jiang H, Powers TR. Curvature-Driven Lipid Sorting in a Membrane Tubule. Phys Rev Lett (2008) 101:18103. doi: 10.1103/PhysRevLett.101.018103

168. Tzaban S, Massol RH, Yen E, Hamman W, Frank SR, Lapierre LA, et al. The Recycling and Transcytotic Pathways for IgG Transport by FcRn Are Distinct and Display an Inherent Polarity. J Cell Biol (2009) 185:673-84. doi: $10.1083 /$ jcb.200809122

169. Claypool SM, Dickinson BL, Wagner JS, Johansen F-E, Venu N, Borawski JA, et al. Bidirectional Transepithelial IgG Transport by a Strongly Polarized Basolateral Membrane Fcy-Receptor. Mol Biol Cell (2004) 15:1746-59. doi: 10.1091/mbc.e03-11-0832

170. Dickinson BL, Badizadegan K, Wu Z, Ahouse JC, Zhu X, Simister NE, et al. Bidirectional FcRn-Dependent IgG Transport in a Polarized Human Intestinal Epithelial Cell Line. J Clin Invest (1999) 104:903-11. doi: $10.1172 / J C I 6968$ 
171. Israel EJ, Taylor S, Wu Z, Mizoguchi E, Blumberg RS, Bhan A, et al. Expression of the Neonatal Fc Receptor, FcRn, on Human Intestinal Epithelial Cells. Immunology (1997) 92:69-74. doi: 10.1046/j.1365-2567.1997.00326.x

172. Hornby PJ, Cooper PR, Kliwinski C, Ragwan E, Mabus JR, Harman B, et al. Human and Non-Human Primate Intestinal FcRn Expression and Immunoglobulin G Transcytosis. Pharm Res (2014) 31:908-22. doi: $10.1007 /$ s11095-013-1212-3

173. Zhou J, Li C, Zhao G, Chu H, Wang D, Yan HH-N, et al. Human Intestinal Tract Serves as an Alternative Infection Route for Middle East Respiratory Syndrome Coronavirus. Sci $A d v$ (2017) 3:eaao4966. doi: 10.1126/sciadv.aao4966

174. Zhou J, Li C, Liu X, Chiu MC, Zhao X, Wang D, et al. Infection of Bat and Human Intestinal Organoids by SARS-CoV-2. Nat Med (2020) 26:1077-83. doi: 10.1038/s41591-020-0912-6

175. Krüger J, Groß R, Conzelmann C, Müller JA, Koepke L, Sparrer KMJ, et al. Drug Inhibition of SARS-CoV-2 Replication in Human Pluripotent Stem Cell-Derived Intestinal Organoids. Cell Mol Gastroenterol Hepatol (2021) 11:935-48. doi: 10.1016/j.jcmgh.2020.11.003

176. Han Y, Duan X, Yang L, Nilsson-Payant BE, Wang P, Duan F, et al. Identification of SARS-CoV-2 Inhibitors Using Lung and Colonic Organoids. Nature (2021) 589:270-5. doi: 10.1038/s41586-020-2901-9

177. Suzuki T, Itoh Y, Sakai Y, Saito A, Okuzaki D, Motooka D, et al. Generation of Human Bronchial Organoids for SARS-CoV-2 Research. bioRxiv (2020). doi: $10.1101 / 2020.05 .25 .115600$

178. Yang L, Han Y, Nilsson-Payant BE, Gupta V, Wang P, Duan X, et al. A Human Pluripotent Stem Cell-Based Platform to Study SARS-CoV-2 Tropism and Model Virus Infection in Human Cells and Organoids. Cell Stem Cell (2020) 27:125-36.e7. doi: 10.1016/j.stem.2020.06.015

179. Yi SA, Nam KH, Yun J, Gim D, Joe D, Kim YH, et al. Infection of Brain Organoids and 2D Cortical Neurons With SARS-CoV-2 Pseudovirus. Viruses (2020) 12:1004. doi: 10.3390/v12091004

180. Ramani A, Müller L, Ostermann PN, Gabriel E, Abida-Islam P, MüllerSchiffmann A, et al. SARS-CoV-2 Targets Neurons of 3D Human Brain Organoids. EMBO J (2020) 39:e106230. doi: 10.15252/embj.2020106230

181. Jacob F, Pather SR, Huang W-K, Zhang F, Wong SZH, Zhou H, et al. Human Pluripotent Stem Cell-Derived Neural Cells and Brain Organoids Reveal SARS-CoV-2 Neurotropism Predominates in Choroid Plexus Epithelium. Cell Stem Cell (2020) 27:937-950.e9. doi: 10.1016/j.stem.2020.09.016

182. Bullen CK, Hogberg HT, Bahadirli-Talbott A, Bishai WR, Hartung T, Keuthan C, et al. Infectability of Human BrainSphere Neurons Suggests Neurotropism of SARS-CoV-2. ALTEX (2020) 37:665-71. doi: 10.14573/altex.2006111

183. Zhang B-Z, Chu H, Han S, Shuai H, Deng J, Hu Y, et al. SARS-CoV-2 Infects Human Neural Progenitor Cells and Brain Organoids. Cell Res (2020) 30:928-31. doi: 10.1038/s41422-020-0390-x

184. Monteil V, Kwon H, Prado P, Hagelkrüys A, Wimmer RA, Stahl M, et al. Inhibition of SARS-CoV-2 Infections in Engineered Human Tissues Using Clinical-Grade Soluble Human Ace2. Cell (2020) 181:905-913.e7. doi: 10.1016/j.cell.2020.04.004

185. Ryan H, Simmons CS. Potential Applications of Microfluidics to Acute Kidney Injury Associated With Viral Infection. Cell Mol Bioeng (2020) 13:305-11. doi: 10.1007/s12195-020-00649-6

186. Roy N, Kashyap J, Verma D, Tyagi RK, Prabhakar A. Prototype of a Smart Microfluidic Platform for the Evaluation of SARS-Cov-2 Pathogenesis, Along With Estimation of the Effectiveness of Potential Drug Candidates and Antigen-Antibody Interactions in Convalescent Plasma Therapy. Trans Indian Natl Acad Eng (2020) 5:241-50. doi: 10.1007/s41403-020-00148-0

187. Shpichka A, Bikmulina P, Peshkova M, Kosheleva N, Zurina I, Zahmatkesh E, et al. Engineering a Model to Study Viral Infections: Bioprinting, Microfluidics, and Organoids to Defeat Coronavirus Disease 2019 (COVID-19). Int J Bioprinting (2020) 6:302. doi: 10.18063/ijb.v6i4.302

188. Tang H, Abouleila Y, Si L, Ortega-Prieto AM, Mummery CL, Ingber DE, et al. Human Organs-On-Chips for Virology. Trends Microbiol (2020) 28:934-46. doi: 10.1016/j.tim.2020.06.005

189. Glebov OO. Understanding SARS-CoV-2 Endocytosis for COVID-19 Drug Repurposing. FEBS J (2020) 287:3664-71. doi: 10.1111/febs.15369

190. Vercauteren D, Vandenbroucke RE, Jones AT, Rejman J, Demeester J, De Smedt SC, et al. The Use of Inhibitors to Study Endocytic Pathways of Gene Carriers: Optimization and Pitfalls. Mol Ther (2010) 18:561-9. doi: 10.1038/ mt.2009.281
191. Sharma RK, Sehgal S, Sachdeva N, Kumar R, Gupta A. Direct Engagement of TLR9 Ligand With T Helper Cells Leads to Cell Proliferation \& UpRegulation of Cytokines. Immunol Invest (2019) 48:79-95. doi: 10.1080/ 08820139.2018.1515223

192. Morgan EH, Iacopetta BJ. Vinblastine But Not Other Microtubule Inhibitors Block Transferrin Endocytosis and Iron Uptake by Reticulocytes. Clin Exp Pharmacol Physiol (1987) 14:119-26. doi: 10.1111/j.1440-1681.1987.tb00965.x

193. Otomo M, Takahashi K, Miyoshi H, Osada K, Nakashima H, Yamaguchi N. Some Selective Serotonin Reuptake Inhibitors Inhibit Dynamin I Guanosine Triphosphatase (GTPase). Biol Pharm Bull (2008) 31:1489-95. doi: 10.1248/ bpb.31.1489

194. Takahashi K, Miyoshi H, Otomo M, Osada K, Yamaguchi N, Nakashima H. Suppression of Dynamin GTPase Activity by Sertraline Leads to Inhibition of Dynamin-Dependent Endocytosis. Biochem Biophys Res Commun (2010) 391:382-7. doi: 10.1016/j.bbrc.2009.11.067

195. Tomkiewicz RP, App EM, Zayas JG, Ramirez O, Church N, Boucher RC, et al. Amiloride Inhalation Therapy in Cystic Fibrosis. Influence on Ion Content, Hydration, and Rheology of Sputum. Am Rev Respir Dis (1993) 148:1002-7. doi: 10.1164/ajrccm/148.4_Pt_1.1002

196. Lin H-P, Singla B, Ghoshal P, Faulkner JL, Cherian-Shaw M, O'Connor PM, et al. Identification of Novel Macropinocytosis Inhibitors Using a Rational Screen of Food and Drug Administration-Approved Drugs. Br J Pharmacol (2018) 175:3640-55. doi: 10.1111/bph.14429

197. Lenze EJ, Mattar C, Zorumski CF, Stevens A, Schweiger J, Nicol GE, et al. Fluvoxamine vs Placebo and Clinical Deterioration in Outpatients With Symptomatic COVID-19. JAMA (2020) 324:2292. doi: 10.1001/jama.2020.22760

198. Chitsike L, Duerksen-Hughes PJ. PPI Modulators of E6 as Potential Targeted Therapeutics for Cervical Cancer: Progress and Challenges in Targeting E6. Molecules (2021) 26:3004. doi: 10.3390/molecules26103004

199. Ramirez J, Poirson J, Foltz C, Chebaro Y, Schrapp M, Meyer A, et al. Targeting the Two Oncogenic Functional Sites of the HPV E6 Oncoprotein With a High-Affinity Bivalent Ligand. Angew Chemie Int Ed (2015) 54:795862. doi: 10.1002/anie.201502646

200. Karlsson OA, Ramirez J, Öberg D, Malmqvist T, Engström Å, Friberg M, et al. Design of a PDZbody, a Bivalent Binder of the E6 Protein From Human Papillomavirus. Sci Rep (2015) 5:9382. doi: 10.1038/srep09382

201. Tian Y-S, Kawashita N, Arai Y, Okamoto K, Takagi T. Pharmacophore Modeling and Molecular Docking Studies of Potential Inhibitors to E6 PBMPDZ From Human Papilloma Virus (HPV). Bioinformation (2015) 11:4016. doi: $10.6026 / 97320630011401$

202. Gogl G, Tugaeva KV, Eberling P, Kostmann C, Trave G, Sluchanko NN. Hierarchized Phosphotarget Binding by the Seven Human 14-3-3 Isoforms. Nat Commun (2021) 12:1677. doi: 10.1038/s41467-021-21908-8

203. Ragia G, Manolopoulos VG. Inhibition of SARS-CoV-2 Entry Through the ACE2/TMPRSS2 Pathway: A Promising Approach for Uncovering Early COVID-19 Drug Therapies. Eur J Clin Pharmacol (2020) 76:1623-30. doi: $10.1007 /$ s00228-020-02963-4

204. Wang K, Chen W, Zhang Z, Deng Y, Lian J-Q, Du P, et al. CD147-Spike Protein Is a Novel Route for SARS-CoV-2 Infection to Host Cells. Signal Transduct Target Ther (2020) 5:283. doi: 10.1038/s41392-020-00426-x

Conflict of Interest: The authors declare that the research was conducted in the absence of any commercial or financial relationships that could be construed as a potential conflict of interest.

Publisher's Note: All claims expressed in this article are solely those of the authors and do not necessarily represent those of their affiliated organizations, or those of the publisher, the editors and the reviewers. Any product that may be evaluated in this article, or claim that may be made by its manufacturer, is not guaranteed or endorsed by the publisher.

Copyright $(2021$ Knyazev, Nersisyan and Tonevitsky. This is an open-access article distributed under the terms of the Creative Commons Attribution License (CC BY). The use, distribution or reproduction in other forums is permitted, provided the original author(s) and the copyright owner(s) are credited and that the original publication in this journal is cited, in accordance with accepted academic practice. No use, distribution or reproduction is permitted which does not comply with these terms. 